Article

\title{
Expression Changes and Impact of the Extracellular Matrix on Etoposide Resistant Human Retinoblastoma Cell Lines
}

\author{
Jacqueline Reinhard ${ }^{1, *}$, Natalie Wagner ${ }^{1}$, Miriam M. Krämer ${ }^{1}$, Marvin Jarocki ${ }^{1}$, \\ Stephanie C. Joachim ${ }^{2} \mathbb{D}$, H. Burkhard Dick ${ }^{2}$, Andreas Faissner ${ }^{1,+}{ }^{+}$and \\ Vinodh Kakkassery $2,3, *,+$ \\ 1 Department of Cell Morphology and Molecular Neurobiology, Faculty of Biology and Biotechnology, \\ Ruhr-University Bochum, Universitaetsstrasse 150, 44780 Bochum, Germany; natalie.wagner@rub.de (N.W.); \\ miriam.kraemer@rub.de (M.M.K.); marvin.jarocki@rub.de (M.J.); andreas.faissner@rub.de (A.F.) \\ 2 Experimental Eye Research Institute, University Eye Hospital, Ruhr-University Bochum, In der Schornau \\ 23-25, 44892 Bochum, Germany; stephanie.joachim@rub.de (S.C.J.); Burkhard.Dick@kk-bochum.de (H.B.D.) \\ 3 Department of Ophthalmology, University of Luebeck, Ratzeburger Allee 160, 23538 Luebeck, Germany \\ * Correspondence: jacqueline.reinhard@rub.de (J.R.); vinodh.kakkassery@gmail.com (V.K.); \\ Tel.: +49-234-32-24-314 (J.R.); +49-451-500-43911 (V.K.); Fax: +49-234-32-143-13 (J.R.); +49-451-500-43914 (V.K.) \\ + These authors contributed equally to this work.
}

Received: 9 April 2020; Accepted: 10 June 2020; Published: 17 June 2020

\begin{abstract}
Retinoblastoma (RB) represents the most common malignant childhood eye tumor worldwide. Several studies indicate that the extracellular matrix (ECM) plays a crucial role in tumor growth and metastasis. Moreover, recent studies indicate that the ECM composition might influence the development of resistance to chemotherapy drugs. The objective of this study was to evaluate possible expression differences in the ECM compartment of the parental human cell lines WERI-RB1 (retinoblastoma 1) and Y79 and their Etoposide resistant subclones via polymerase chain reaction (PCR). Western blot analyses were performed to analyze protein levels. To explore the influence of ECM molecules on RB cell proliferation, death, and cluster formation, WERI-RB1 and resistant WERI-ETOR cells were cultivated on Fibronectin, Laminin, Tenascin-C, and Collagen IV and analyzed via time-lapse video microscopy as well as immunocytochemistry. We revealed a significantly reduced mRNA expression of the proteoglycans Brevican, Neurocan, and Versican in resistant WERI-ETOR compared to sensitive WERI-RB1 cells. Also, for the glycoproteins $\alpha 1$-Laminin, Fibronectin, Tenascin- $C$, and Tenascin-R as well as Collagen IV, reduced expression levels were observed in WERI-ETOR. Furthermore, a downregulation was detected for the matrix metalloproteinases $M M P 2, M M P 7, M M P 9$, the tissue-inhibitor of metalloproteinase TIMP2, the Integrin receptor subunits ITGA4, ITGA5 and ITGB1, and all receptor protein tyrosine phosphatase $\beta / \zeta$ isoforms. Downregulation of Brevican, Collagen IV, Tenascin-R, MMP2, TIMP2, and ITGA5 was also verified in Etoposide resistant Y79 cells compared to sensitive ones. Protein levels of Tenascin-C and MMP-2 were comparable in both WERI cell lines. Interestingly, Fibronectin displayed an apoptosis-inducing effect on WERI-RB1 cells, whereas an anti-apoptotic influence was observed for Tenascin-C. Conversely, proliferation of WERI-ETOR cells was enhanced on Tenascin-C, while an anti-proliferative effect was observed on Fibronectin. In WERI-ETOR, cluster formation was decreased on the substrates Collagen IV, Fibronectin, and Tenascin-C. Collectively, we noted a different ECM mRNA expression and behavior of Etoposide resistant compared to sensitive RB cells. These findings may indicate a key role of ECM components in chemotherapy resistance formation of RB.
\end{abstract}

Keywords: chemotherapy resistance; etoposide; extracellular matrix; integrins; retinoblastoma; WERI-RB1; Y79 


\section{Introduction}

Retinoblastoma (RB) has an incidence rate of 1 in 15,000-20,000 live births. With approximately $8,000-9,000$ new cases every year, it is the most common malignant pediatric ocular tumor worldwide [1-4]. RB is highly curable when diagnosed early and treated appropriately. Due to an improvement of therapeutic strategies over recent years, the survival rate is nearby $99 \%$ in developing countries, while in Africa or Asia death rates are still high [5-7].

Two types of RB can be distinguished, namely the spontaneous and the inherited form. Both forms are caused by an inactivation of the retinoblastoma 1 (RB1) tumor suppressor gene. Therefore, RB displays an excellent model for RB1 protein eliminated tumors.

RB tumor usually manifests in children before the age of five. All RB treatment options follow the priority to preserve the child's life. The highest chance to reduce lethality dramatically from $95 \%$ to $5 \%$ in RB, is to surgically remove the affected eye [8]. To prevent eye removal in children, further chemotherapy, cryotherapy, photocoagulation, radiotherapy, or combined strategies were introduced over the last decades $[8,9]$. Especially chemotherapy is effective in tumor control. Low rates of secondary CNS malignancies in RB are a major benefit of chemotherapy in comparison to radiation therapy [10-17]. Therefore, chemotherapy has been established as first-line therapy in RB. Nevertheless, chemotherapy resistance, also for Etoposide, limits eye preserving therapy [18].

Several studies described that a dysregulation of the extracellular matrix (ECM) plays a crucial role in tumor growth, progression, metastasis, and angiogenesis [19-24]. Also, ECM interacting enzymes such as matrix metalloproteinases (MMPs) and tissue-inhibitors of metalloproteinases (TIMPs) as well as receptors like Integrins represent important modifying components in tumor tissue [25,26]. Moreover, studies indicate that the ECM composition might influence resistance development to various chemotherapeutic drugs $[27,28]$. Thus, understanding the exact ECM composition in RB and other tumors and its role in chemotherapeutic drug resistance is of great interest to improve and develop novel treatment strategies.

Due to the cancer stem cell (CSC) hypothesis, it was proposed that cancer arises from a small population of self-sustaining cancer cells, which exhibit self-renewal and maintenance capacity. Regarding this finding, we recently reviewed that CSCs and neural stem cells share a similar ECM compartment [29]. Preceding studies also reported the presence of stem cells in human RB [30-33]. Moreover, Jia et al. noted that multidrug resistance might play a key role in RB CSCs isolated from the WERI-RB1 cell line [18]. Expression of multidrug resistance proteins was also described in human primary RB Y79 cultures after exposure to chemotherapeutic agents, including Etoposide [34]. In this regard, an improved knowledge of chemotherapy resistance is crucial when conceptualizing new treatment strategies.

The aim of the present study was to evaluate the potential role of the ECM in retinoblastoma chemotherapy resistance. Accordingly, we analyzed different human RB cell lines. The parental cell line WERI-RB1 was initially established by McFall and colleagues and is sensitive to Etoposide [35]. The WERI-ETOR cell line represents a described Etoposide resistant subclone of this parental cell line [36-38]. Additionally, the parental Y79 RB cell line, first described by Reid et al. [39], and a resistant Y79 subclone were investigated.

Via PCR, expression levels of various ECM proteoglycans and glycoproteins were analyzed and compared in the Etoposide sensitive and resistant RB cell lines. Furthermore, the mRNA regulation of ECM degrading MMPs and counteracting TIMPs as well as of important ECM receptors, namely Integrin receptor subunits and receptor protein tyrosine phosphatase (RPTP) $\beta / \zeta$ isoforms was explored. Additionally, protein levels of Tenascin-C and MMP-2 were examined via Western blot analyses in WERI cell lines. Finally, the impact of various ECM components on cellular death, proliferation and cluster formation was investigated by time-lapse video microscopy as well as immunocytochemistry. 


\section{Results}

\subsection{CSPG mRNA Expression in WERI-RB1 and WERI-ETOR}

Proteoglycans are major constituents of the ECM. In order to characterize the expression of the CSPGs Aggrecan (ACAN), Brevican (BCAN), Neurocan (NCAN), and Versican (VCAN) in Etoposide sensitive and resistant cells, quantitative real-time PCR (RT-qPCR) analyses were performed (Figure 1A). The analyses revealed a comparable mRNA expression level for $A C A N$ in both cell lines (0.758-fold; $p=0.16)$. In contrast, a prominent downregulation of the BCAN (0.064-fold; $p<0.001)$ as well as VCAN (0.075-fold; $p<0.001)$ mRNA expression level was observed in the resistant WERI-ETOR compared to the sensitive WERI-RB1 cells. Also, for NCAN, a significantly reduced expression level was found in the WERI-ETOR cell line (0.682-fold; $p=0.003)$.

A

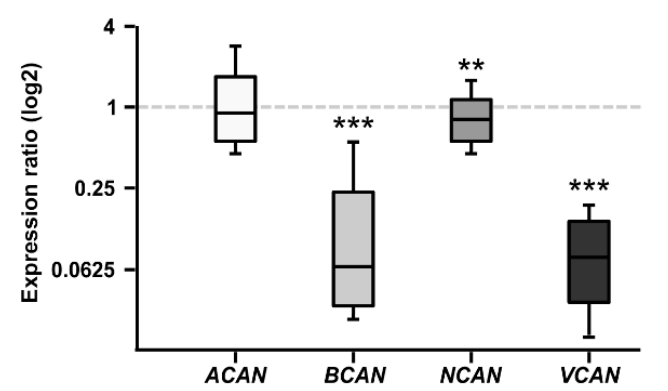

C

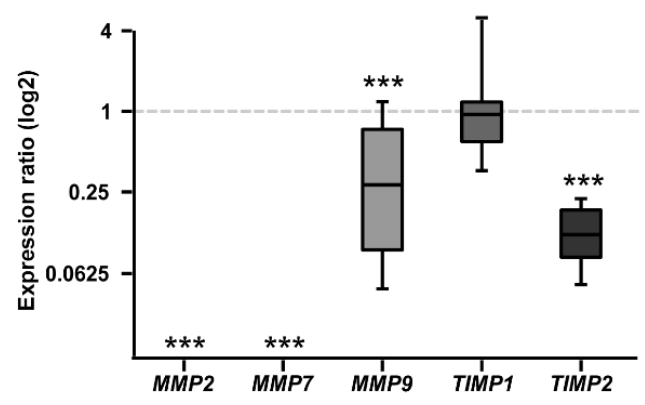

B

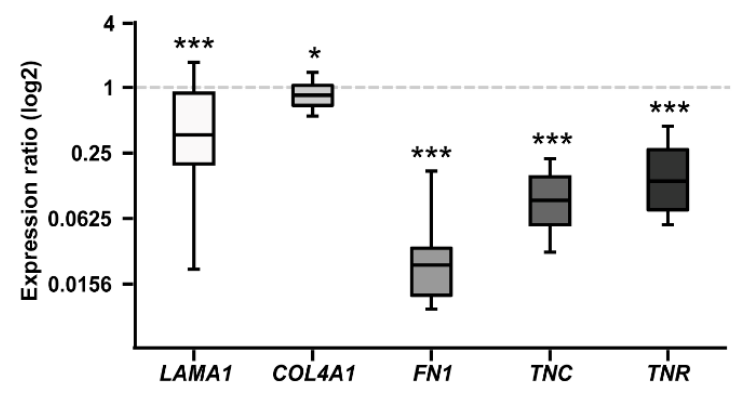

D

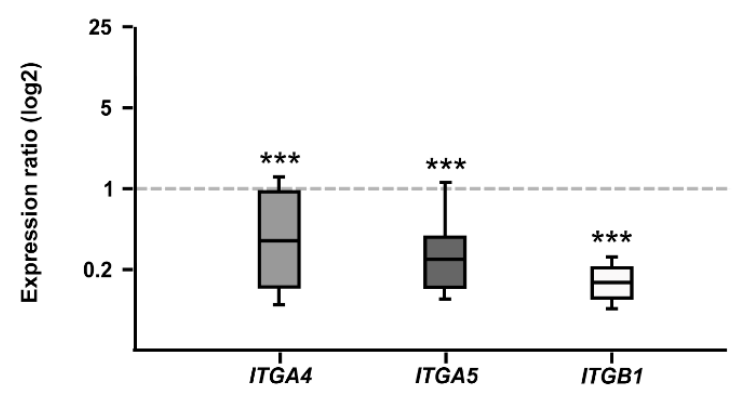

Figure 1. RT-qPCR analyses of relative CSPG, extracellular matrix (ECM) glycoprotein, matrix metalloproteinases (MMPs), tissue-inhibitor of metalloproteinases (TIMPs), and Integrin mRNA expression in the WERI-ETOR compared to the WERI-RB1 cell line. (A) In the resistant WERI-ETOR cell line, significantly reduced levels of Brevican (BCAN), Neurocan (NCAN), and Versican (VCAN) were observed. In contrast, Aggrecan ( $A C A N)$ expression was comparable in both WERI cell lines. (B) A significant downregulation was observed for all ECM glycoproteins ( $\alpha 1$-Laminin (LAMA1), Fibronectin (FN1), Tenascin-C (TNC), and Tenascin-R (TNR)) as well as for Collagen IV (COL4A1). (C) Significant lower expression levels were detected for $M M P 2, M M P 7, M M P 9$, and TIMP2. While TIMP1 expression was similar in both WERI cell lines. (D) In the WERI-ETOR cell line, significantly reduced levels of integrin receptor subunits ITGA4, ITGA5, and ITGB1 were noted. Values are median \pm quartile + maximum/minimum. The dotted line in the graphs represents the relative expression level of the WERI-RB1 cell line. ${ }^{*} p<0.05 ;{ }^{* *} p<0.01 ;{ }^{* * *} p<0.001 ; n=10$ /group.

\subsection{Expression of ECM Glycoproteins in WERI-RB1 and WERI-ETOR}

Next, the mRNA expression of the glycoproteins a1-Laminin (LAMA1), Fibronectin (FN1), Tenascin-C (TNC), and Tenascin-R (TNR) was analyzed in both WERI cell lines (Figure 1B). Additionally, the expression of Collagen IV (COL4A1) was investigated. As revealed by RT-qPCR, both LAMA1 (0.373-fold; $p=0.001)$ and FN1 (0.023-fold; $p<0.001)$ displayed a significantly lower expression in WERI-ETOR compared to WERI-RB1 cells. Also, for COL4A1 a reduced mRNA expression level 
was detected in the WERI-ETOR cell line $(0.852 ; p=0.046)$. For both analyzed Tenascins, namely TNC (0.091-fold; $p=0.001)$ and TNR $(0.137$-fold; $p<0.001)$, the mRNA expression level was significantly lower in WERI-ETOR cells.

To further investigate TNC protein levels, Western blot analyses were performed. However, similar TNC protein levels (WERI-RB1: $1.01 \pm 0.51$ relative units; WERI-ETOR: $1.09 \pm 0.63$ rel. units; $p=0.84$ ) were found in both WERI cell lines (Figure A1).

\subsection{Expression of MMPs and TIMPs in WERI-RB1 and WERI-ETOR}

Remodeling of the ECM is primarily mediated by MMPs and counteracting TIMPs. MMPs, and TIMPs play a key role in tumor cell adhesion [40]. Therefore, RT-qPCR analyses were performed to analyze the mRNA expression pattern of MMP-2 (MMP2), MMP-7 (MMP7), and MMP-9 (MMP9) as well as TIMP-1 (TIMP1) and TIMP-2 (TIMP2; Figure 1C). Interestingly, MMP2 and MMP7 mRNA expression was detectable at lowest levels in WERI-ETOR cells $(p<0.001)$. Also, the expression of MMP9 was significantly decreased in the WERI-ETOR compared to the WERI-RB1 cell line (0.314-fold; $p<0.001)$. The expression of TIMP1 was comparable in both WERI groups (1.038-fold; $p=0.09)$. In contrast, TIMP2 expression was significantly reduced in WERI-ETOR cells $(0.135$-fold; $p<0.001)$.

In order to investigate MMP-2 protein levels, Western blot analyses were conducted. Here, pro- and active-MMP-2 proteins were observed in both cell lines at a comparable level (WERI-RB1: $1.23 \pm 0.03$ rel. units; WERI-ETOR: $1.29 \pm 0.06$ rel. units; $p=0.63$; Figure A2).

\subsection{Expression of Integrin Receptor Subunits in WERI-RB1 and WERI-ETOR}

Integrins represent important ECM receptors and have been implicated in tumor progression as well as tumor cell migration and proliferation [41,42]. To better understand the potential role of Integrins in RB and resistance development, the mRNA expression levels of the Integrin receptor subunits $\alpha 4$ (ITGA4), $\alpha 5$ (ITGA5), and $\beta 1$ (ITGB1) were analyzed in both WERI cell lines via RT-qPCR (Figure 1D). Our examination of Integrin levels revealed a significantly reduced mRNA expression of $\alpha 4$-Integrin (ITGA4; 0.285-fold; $p=0.03$ ), $\alpha 5$-Integrin (ITGA5; 0.198-fold; $p<0.001$ ) and $\beta 1$-Integrin (ITGB1; 0.126-fold; $p<0.001$ ) in WERI-ETOR cells.

2.5. Expression of CSPGs, ECM Glycoproteins, MMPs, TIMPs, and Integrin Receptor Subunits in Etoposide Sensitive and Resistant Y79 RB cells

In order to further explore the mRNA expression levels of CSPGs, ECM glycoproteins, MMPs, TIMPs and Integrin receptor subunits in an independent human RB cell line, we analyzed Etoposid sensitive and resistant Y79 cells by RT-qPCR (Figure A3).

As shown for the WERI-ETOR cell line, our analyses verified a significantly reduced expression level of the proteoglycan BCAN (0.262-fold; $p<0.001)$, COL4A1 (0.625-fold; $p=0.018)$, and the ECM glycoprotein TNR $(0.043 ; p=0.001)$ in Etoposid resistant $Y 79$ cells compared to the sensitive Y79 cell line. Also, MMP2 (0.210-fold; $p<0.001)$, TIMP2 (0.527-fold; $p=0.002)$ as well as ITGA5 (0.029-fold; $p=0.003$ ) displayed a reduced expression in this group. Furthermore, a comparable expression level for ACAN (1.062-fold; $p=0.761$ ) was found in both Y79 cell lines, as noted for both WERI cell lines. Comparable to the effects in resistant WERI-ETOR cells, resistant Y79 cells often showed a slightly lower expression. However, overall a comparable FN1 (0.888-fold; $p=0.686)$, TNC (1.463-fold; $p=0.353)$, MMP9 (0.788-fold; $p=0.397)$, ITGA4 (0.762-fold; $p=0.419)$, and ITGB1 (1.130-fold; $p=0.254)$ expression level was seen. Contrary to the findings in the resistant WERI-ETOR cell line, expression of NCAN (2.207-fold; $p=0.005), V C A N$ (4.121-fold; $p<0.001), L A M A 1$ (1.598-fold; $p=0.01)$ as well as of TIMP1 (3.025-fold; $p=0.001$ ) was significantly upregulated in the Y79 cell line. Although MMP7 was expressed at lowest levels in the WERI-ETOR compared to the WERI-RB1 cells, its expression was not detectable in both Y79 cell lines. 


\subsection{Expression of RPTP $\beta / \zeta$ Isoforms in WERI-RB1 and WERI-ETOR}

$R P T P \beta / \zeta$ is another member of the CSPG family. By alternative splicing three different $R P T P \beta / \zeta$ (PTPRZ1) isoforms are generated, namely the secreted splice variant Phosphacan and both receptor isoforms $R P T P \beta / \zeta_{\text {long }}$ and $R P T P \beta / \zeta_{\text {short }}$. Phosphacan $/ R P T P \beta / \zeta$ is an important binding partner for Tenascin-C [43,44]. To explore RPTP $\beta / \zeta$ isoform mRNA expression in WERI-RB1 and WERI-ETOR cells, a set of three different primer pairs was used for semi-quantitative RT-PCR analyses (Figure 2A-C).

A

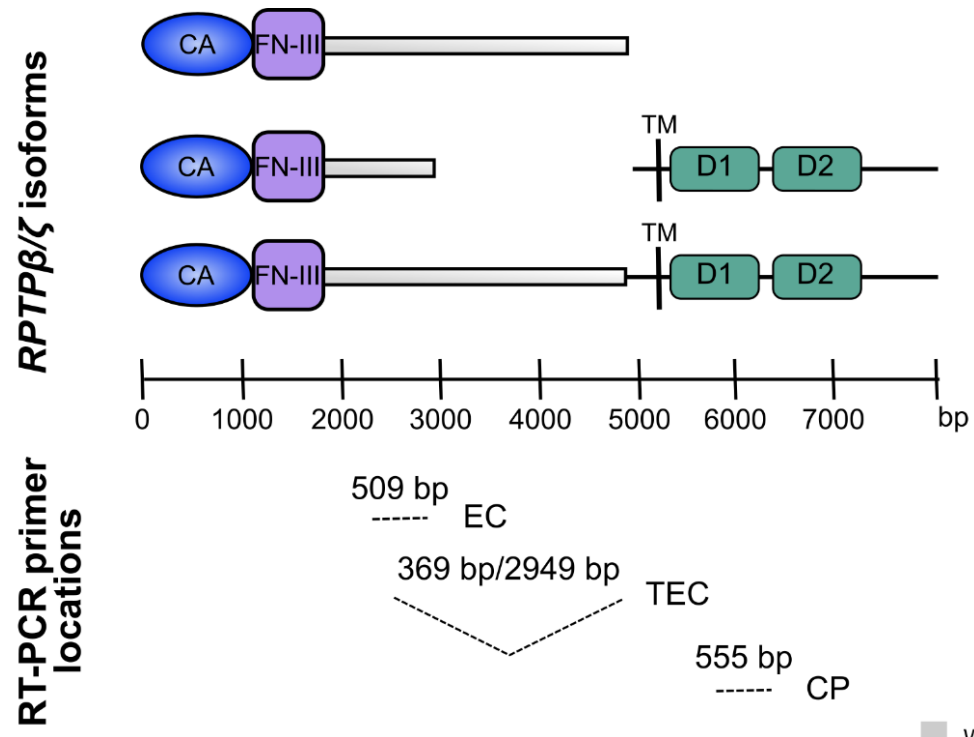

B

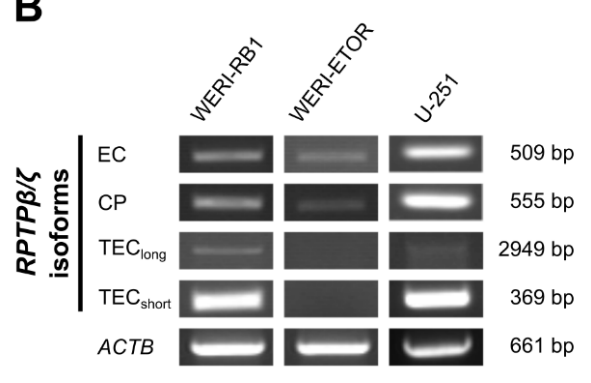

WERI-RB1

WERI-ETOR

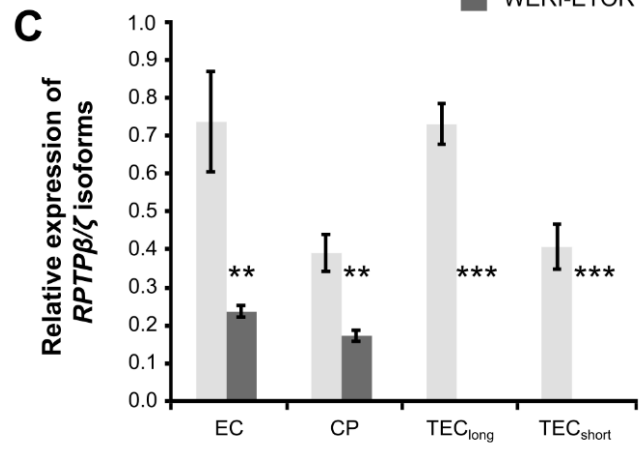

Figure 2. Semi-quantitative RT-PCR analyses of $R P T P \beta /$ isoforms in WERI-RB1 compared to WERI-ETOR cells using various primer sets. (A) Scheme displays binding sites of specific $R P T P \beta / \zeta(P T P R Z 1)$ primer pairs for isoform amplification. All three of the RPTP $\beta / \zeta$ isoforms, which were generated by alternative splicing, exhibit an extracellular carbonic anhydrase-like (CA) domain and Fibronectin-type-III (FN-III) repeats. A set of three distinct primers pairs (EC, TEC, and CP) marks the corresponding nucleotide sequence to demonstrate the resulting amplicon (modified according to Norman and colleagues [45]). (B) Using a set of three different primer pairs, the expression of $R P T P \beta /$ /isoforms was evaluated in both cell lines. The glioblastoma multiforme cell line U-251 served as positive control. The primer pair termed EC amplified a 509 bp product. This amplified product is part of all RPTP $\beta /$ /isoforms. A second primer pair, termed CP, amplified a 555 bp product, which corresponds to both $R P T P \beta / \zeta$ receptor isoforms. Using this primer pair, expression of $R P T P \beta / \zeta_{\text {long/short }}$ was verified in WERI-RB1 cells. In contrast, only little, if any expression, was observed in WERI-ETOR cells. A third primer pair, termed TEC, amplified a $369 \mathrm{bp}\left(R P T P \beta / \zeta_{\text {short }}\right)$ as well as a $2949 \mathrm{bp}\left(R P T P \beta /\right.$ llong $\left._{\text {log }}\right)$ fragment. Both transcripts were verified in the WERI-RB1 line but were absent in the WERI-ETOR cell line. (C) Densitometric measurements of band intensities followed by semi-quantitative analyses and relative quantification (normalized to $A C T B$ expression) revealed a significant downregulation of all RPTP $\beta /$ ¿isoforms in WERI-ETOR compared to WERI-RB1 cells. Values are shown as mean $\pm \mathrm{SD}$. ${ }^{* *} p<0.01 ;{ }^{* * *} p<0.001 ; n=5$ /group. 
According to previous descriptions and as shown for each set schematically, these primer pairs bind to specific regions of the three RPTP $\beta / \zeta$ isoforms (Figure 2A; [45]). The glioblastoma multiforme cell line U-251 served as positive control, since all $R P T P \beta / \zeta$ isoforms are prominently expressed in different grades of glioma types [45].

A primer pair, termed EC, amplified a 509 bp product, which corresponds to a product present in all $R P T P \beta / \zeta$ isoforms. By using this primer pair, semi-quantitative analyses revealed a significant downregulation in WERI-ETOR compared to WERI-RB1 ( $p=0.002$; Figure 2B,C). A second primer pair, termed $\mathrm{CP}$, amplified a $555 \mathrm{bp}$ fragment, located in the cytoplasmic part of $R P T P \beta / \zeta$ and allows the identification of both $R P T P \beta / \zeta$ receptor variants. Using this primer pair, expression of $R P T P \beta / \zeta_{\text {long }} / R P T P \beta / \zeta_{\text {short }}$ was verified in WERI-RB1 cells. In contrast, only little, if any, expression, was observed in WERI-ETOR cells ( $p=0.005$; Figure 2B,C). TEC, a third primer pair, amplified a $2949 \mathrm{bp}$ $\left(R P T P \beta / \zeta_{\text {long }}\right)$ and a $369 \mathrm{bp}\left(R P T P \beta / \zeta_{\text {short }}\right)$ fragment. Both transcripts were verified in the WERI-RB1 line, but, were not detected in the WERI-ETOR cell line $(p<0.001$; Figure 2B,C). In sum, based on the RT-PCR analyses, RPTP $/ /$ isoforms were significantly downregulated in the WERI-ETOR cell line.

\subsection{Impact of the ECM on WERI-RB1 and WERI-ETOR Cell Survival}

Next, the influence of various ECM substrates on apoptosis of WERI-RB1 and WERI-ETOR was investigated by immunocytochemical stainings after 2 days in vitro (div). Dissociated cells were cultivated on wells coated with either Poly-L-Ornithine (non-ECM control substrate) or Poly-L-Ornithine and Collagen IV, Fibronectin, Laminin, and Tenascin-C, respectively. Apoptotic cells were identified by cleaved Caspase 3 immunostaining and nuclear Hoechst co-staining, which allows to monitor nuclear condensation, cell shrinkage, and DNA fragmentation (Figure 3A-K).

On Poly-L-Ornithine, significantly more cleaved Caspase $3^{+}$cells were identified for the WERI-ETOR $(12.18 \pm 1.23 \%)$ compared to the WERI-RB1 cell line $(8.35 \pm 0.61 \% ; p=0.048)$. Cultured on Collagen IV, the percentage of apoptotic WERI-RB1 and WERI-ETOR cells was about the same (WERI-RB1: $8.88 \pm 0.98 \%$; WERI-ETOR: $11.02 \pm 0.44 \% ; p=0.13$ ). However, on Fibronectin, a significantly decreased percentage of cleaved Caspase $3^{+}$cells was observed for the WERI-ETOR $(8.87 \pm 1.08 \%)$ compared to the WERI-RB1 cell line $(21.20 \pm 2.64 \% ; p=0.012)$. For Laminin coating, the number of cleaved Caspase $3^{+}$cells was similar in both cell lines (WERI-RB1: $10.44 \pm 2.28 \%$; WERI-ETOR: $12.87 \pm 4.41 \% ; p=0.65)$. Interestingly, significantly more apoptotic WERI-ETOR cells $(8.33 \pm 1.33 \%)$ were identified on Tenascin-C compared to apoptotic WERI-RB1 cells $(2.78 \pm 0.53 \% ; p=0.02)$. Furthermore, our analyses of the WERI-RB1 cell line revealed a significantly increased number of apoptotic cells on Fibronectin when compared to Poly-L-Ornithine $(p=0.004)$, Collagen IV $(p=0.007)$, Laminin $(p=0.02)$, and Tenascin-C $(p<0.001)$. The WERI-ETOR cell line had a comparable apoptotic rate on all substrates $(p>0.05)$.

\subsection{Influence of the ECM on WERI-RB1 and WERI-ETOR Cell Proliferation}

Additionally, we analyzed whether various ECM substrates influence the proliferation behavior of WERI-RB1 and WERI-ETOR cells. For this purpose, the number of daughter cells, generated by cell divisions over a period of 48 hours, was evaluated by time-lapse video microscopy (Figure 4A,B).

On Poly-L-Ornithine, no differences were found regarding the percentage of generated daughter cells in both cell lines (WERI-RB1: $31.91 \pm 1.81 \%$; WERI-ETOR: $30.93 \pm 2.45 \%$; $p=0.76$ ). Also, a comparable number of cell divisions was observed on Collagen IV in WERI-RB1 $(36.76 \pm 4.54 \%)$ as well as in WERI-ETOR cells $(25.02 \pm 2.91 \% ; p=0.06)$. However, a trend towards a decreased cell division number was obvious in WERI-ETOR. Interestingly, a significant reduction in the number of cell divisions was seen for WERI-ETOR cells when cultivated on Fibronectin (WERI-RB1: $28.27 \pm 2.99 \%$; WERI-ETOR: $16.76 \pm 3.04 \% ; p=0.03$ ). On Laminin and Tenascin-C, no alteration in the percentage of generated daughter cells was noted in WERI-RB1 (Laminin: $30.04 \pm 2.54 \%$; Tenascin-C: $30.50 \pm 1.89 \%$ ) compared to WERI-ETOR cells (Laminin: $23.91 \pm 3.58 \% ; p=0.2$; Tenascin-C: $33.58 \pm 2.42 \%$; $p=0.34$ ). 

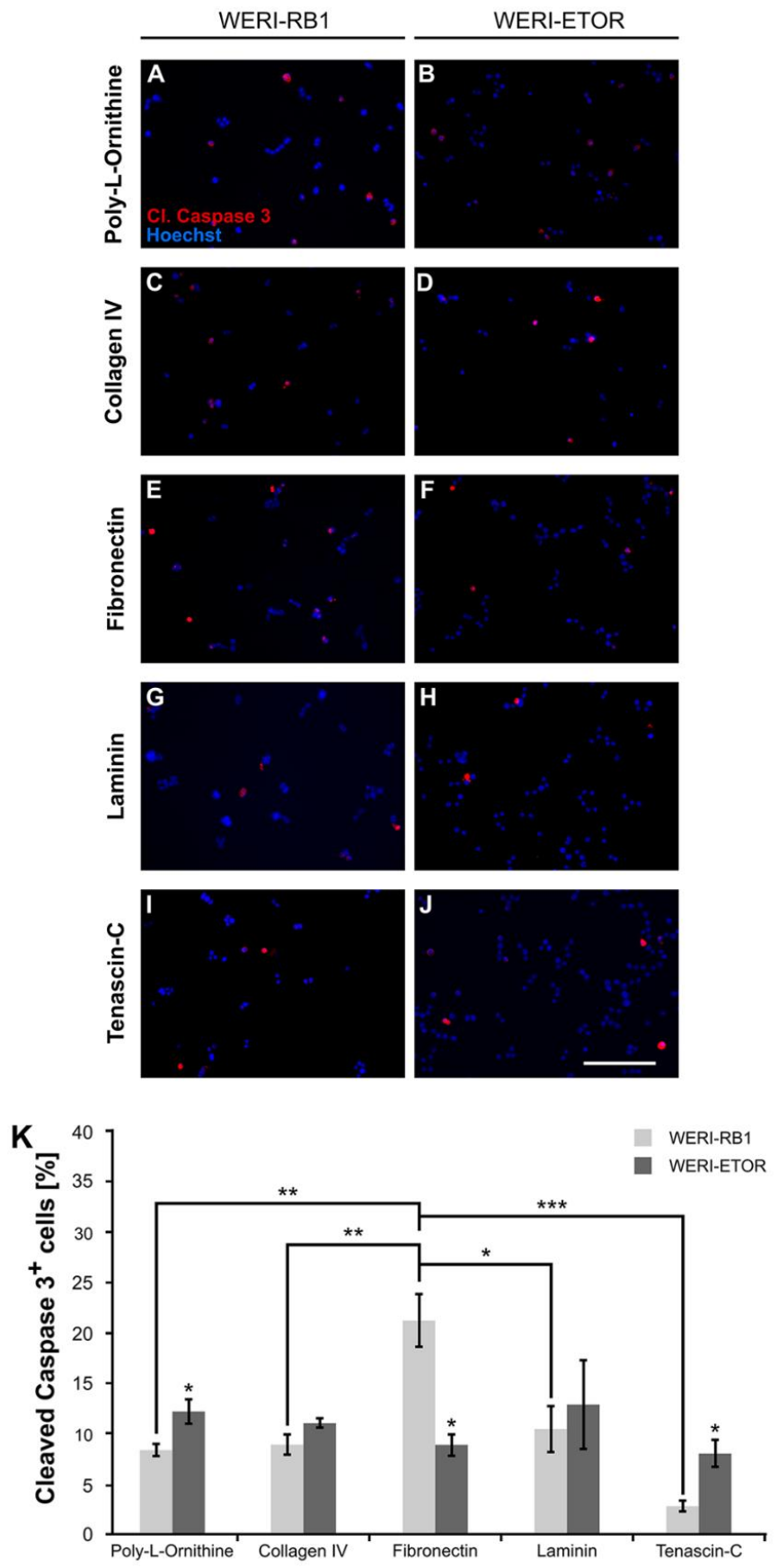

Figure 3. Immunocytochemical detection of apoptotic WERI-RB1 and WERI-ETOR cells cultivated on various ECM substrates. (A-J) Apoptotic cells were identified by cleaved Caspase 3 (cl. Caspase 3) immunostaining (red) and nuclear Hoechst co-staining (blue) in WERI-RB1 (A,C,E,G,I) and WERI-ETOR cells $(\mathbf{B}, \mathbf{D}, \mathbf{F}, \mathbf{H}, \mathbf{J})$. (K) Significantly more cleaved Caspase $3^{+}$cells were identified for the WERI-ETOR compared to the WERI-RB1 cell line when cultivated on the non-ECM control Poly-L-Ornithine or the ECM glycoprotein Tenascin-C. On Collagen IV and Laminin, the percentage of apoptotic WERI-RB1 and WERI-ETOR cells was comparable. In contrast, on Fibronectin, a significantly reduced percentage of cleaved Caspase $3^{+}$cells was observed for WERI-ETOR compared to WERI-RB1 cells. Furthermore, our analyses of the WERI-RB1 cell line revealed a significant increased number of apoptotic cells on Fibronectin when compared to the other substrates. Data are shown as mean \pm SEM. ${ }^{*} p<0.05 ;{ }^{* *} p<0.01 ;{ }^{* * *} p<0.001 ; n=3$ /group. Scale bar $=100 \mu \mathrm{m}$. 
A

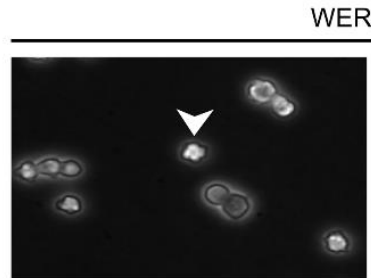

WERI-RB1
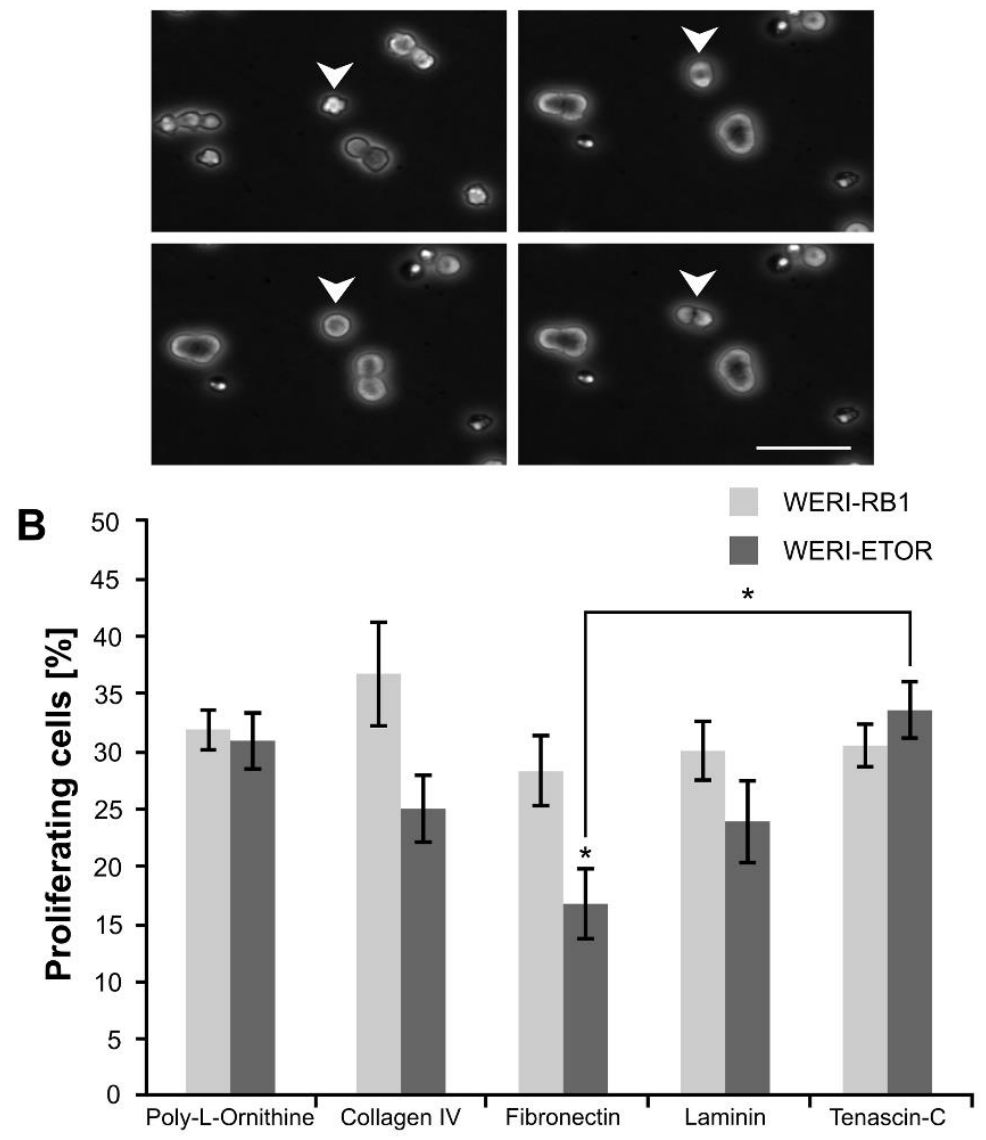

Figure 4. Proliferation analyses via time-lapse video microscopy of WERI-RB1 and WERI-ETOR cells cultivated on various ECM substrates. (A) Representative phase contrast images of proliferative WERI-RB1 cells documented via time-lapse video microscopy. White arrowheads indicate cell division. (B) The percentage of proliferative WERI-RB1 was comparable to the percentage of proliferative WERI-ETOR cells when cultivated on Poly-L-Ornithine (non-ECM control), Collagen IV, Laminin, and Tenascin-C. In contrast, on Fibronectin, a significant reduced percentage of proliferative WERI-ETOR cells was observed. Furthermore, regarding the WERI-ETOR cell line, a significant lower percentage of proliferative cells was found on Fibronectin compared to Tenascin-C. Values are shown as mean \pm SEM. ${ }^{*} p<0.05 ; n=5 /$ group. Scale bar $=50 \mu \mathrm{m}$.

Most interestingly, when compared to Fibronectin coating, WERI-ETOR cells show a significantly increased number of cell divisions when cultivated on Tenascin-C $(p=0.01)$. The WERI-RB1 cells exhibited a similar fraction of proliferating cells on all investigated ECM substrates $(p>0.05)$.

To evaluate the proliferation of both cell lines in more detail, cells were cultivated for 2 div, fixed and immunocytochemically stained with an anti-phospho Histone H3 (PH3) antibody (Figure 5A-K). Cell nuclei were counterstained with Hoechst and $\mathrm{PH}^{+}$M-phase (mitotic-phase) cells were counted.

On Poly-L-Ornithine, the number of M-phase ${ }^{+}$WERI-ETOR cells $(2.14 \pm 0.13 \%)$ was comparable to the number of proliferative WERI-RB1 cells $(1.66 \pm 0.46 \% ; p=0.37)$. When cultivated on Collagen IV, a slightly increased number of PH3 ${ }^{+}$WERI-ETOR cells $(2.43 \pm 0.98 \%)$ was noted compared to WERI-RB1 cells $(0.91 \pm 0.04 \% ; p<0.05)$. Similar numbers of $\mathrm{PH}^{+} \mathrm{M}$-phase cells were detected for both cell lines when cultivated on Fibronectin (WERI-RB1: $1.08 \pm 0.43 \%$; WERI-ETOR: $2.15 \pm 1.09 \% ; p=0.41$ ). The same tendency was observed for both cell lines cultured on Laminin (WERI-RB1: $1.57 \pm 0.38 \%$; WERI-ETOR: $1.81 \pm 0.32 \% ; p=0.65$ ) and Tenascin-C (WERI-RB1: $1.53 \pm 0.05 \%$; WERI-ETOR: $3.49 \pm 2.07 \% ; p=0.40$ ). 
In summary, the different substrates appeared to exhibit no significant influence on the number of $\mathrm{PH}^{+}$M-phase WERI-RB1 and WERI-ETOR cells.

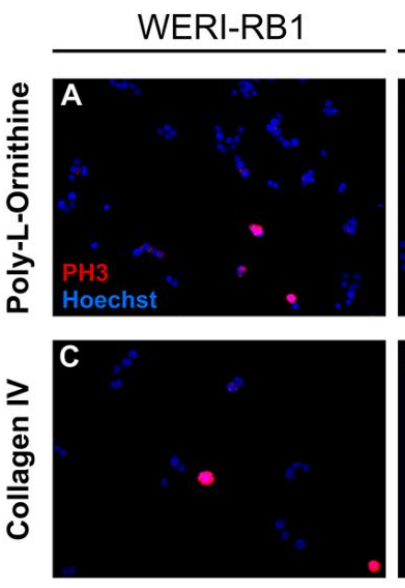

\section{WERI-ETOR}
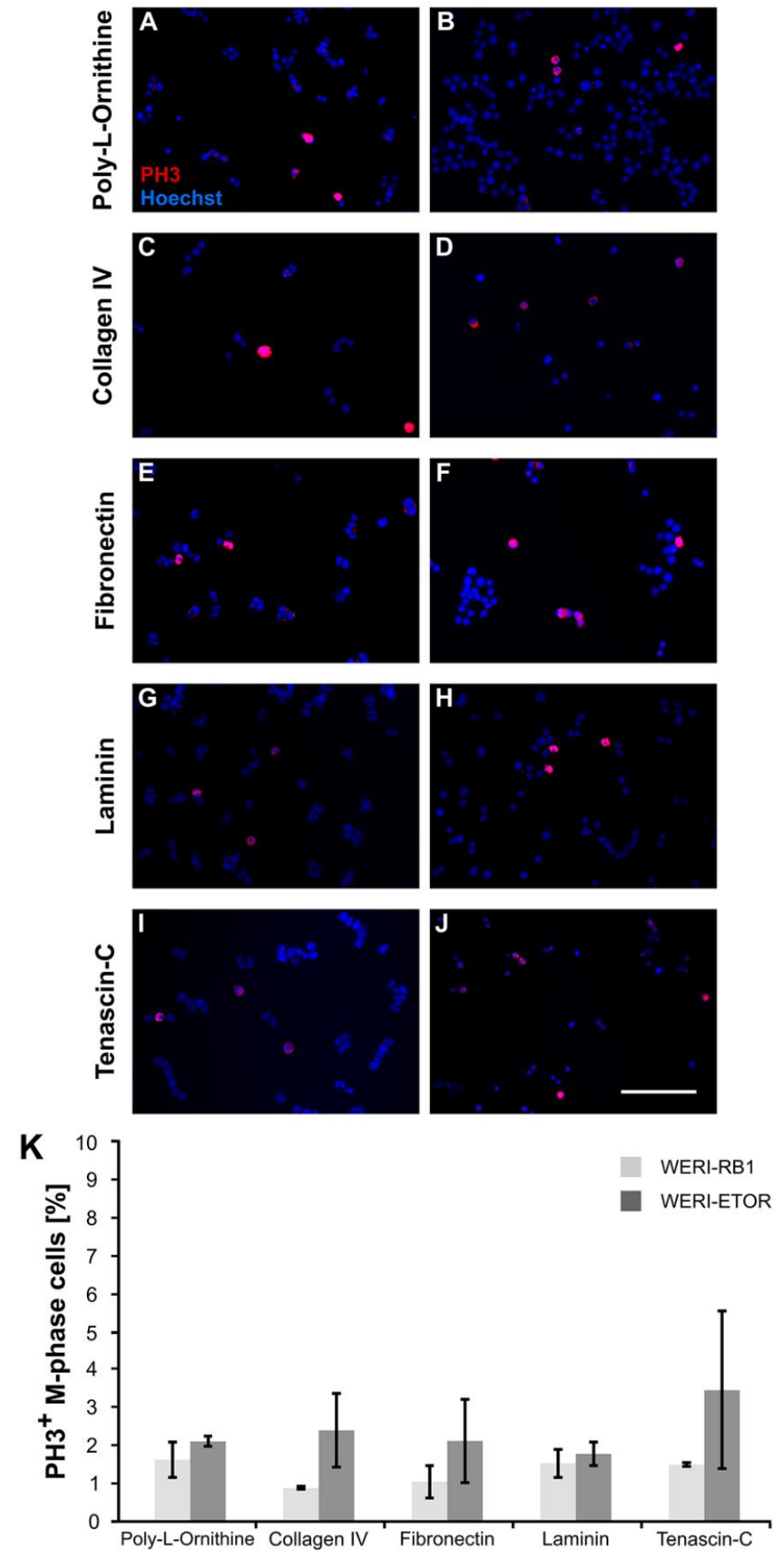

Figure 5. Immunocytochemical detection of $\mathrm{PH}^{+} \mathrm{M}$-phase WERI-RB1 and WERI-ETOR cells cultivated on various ECM substrates. (A-J) Proliferative WERI-RB1 (A,C,E,G,I) and WERI-ETOR (B,D,F,H,J) M-phase cells were identified by PH3 immuno- (red) and nuclear Hoechst co-staining (blue). (K) In both cell lines, counts revealed that the percentage of M-phase cells was comparable when cultivated on Poly-L-Ornithine (non-ECM control), Collagen IV, Fibronectin, Laminin, and Tenascin-C. Values are shown as mean \pm SEM. $n=3$ /group. Scale bar $=100 \mu \mathrm{m}$. 


\subsection{Cluster Formation Capacity of WERI-RB1 and WERI-ETOR Cells on Different ECM Substrates}

In suspension, both WERI cell lines display cluster and chain formation. To investigate cell cluster formation in dependence of various ECM substrates, dissociated cells were analyzed via time-lapse video microscopy. Therefore, the total number of single cells and cell clusters, defined as $\geq 3$ cells, was counted after plating for 0, 8, 16, 24, 32, 40, and 48 hours (Figures 6 and 7).

A
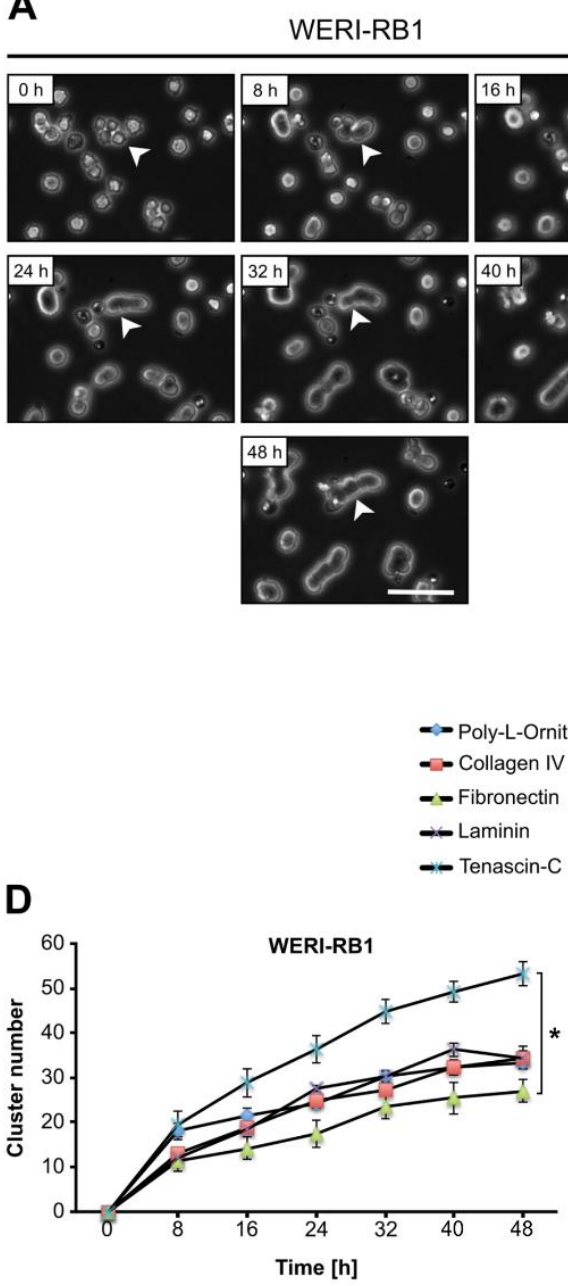

B

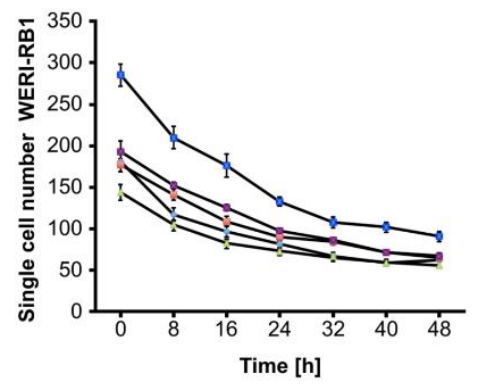

C

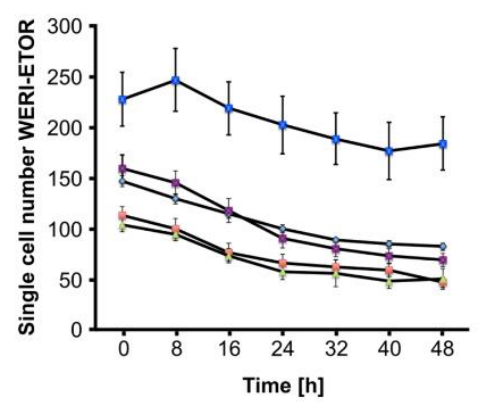

E

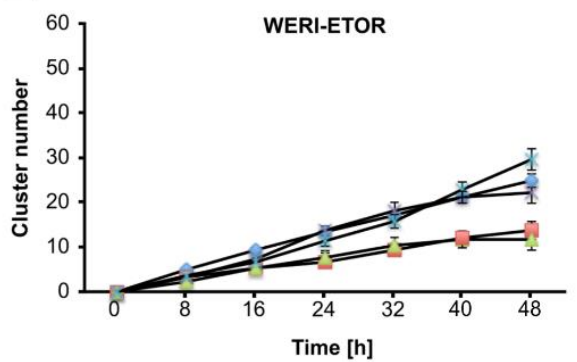

Figure 6. Single cell number and cell cluster formation analyses of WERI-RB1 and WERI-ETOR cells cultivated on various ECM substrates via time-lapse microscopy. (A) Representative phase contrast images of WERI-RB1 cell cluster formation (white arrowhead) as revealed by time-lapse video microscopy over $48 \mathrm{~h}$. $(\mathrm{B}, \mathrm{C})$ The number of single WERI-RB1 and WERI-ETOR cells cultivated on Poly-L-Ornithine (non-ECM control), Collagen IV, Fibronectin, Laminin, and Tenascin-C decreases over time. (D,E) Over $48 \mathrm{~h}$, the number of WERI-RB1 and WERI-ETOR cell clusters was increased when plated on various substrates. Importantly, at $48 \mathrm{~h}$ the WERI-RB1 cells displayed a significantly higher cluster number on Tenascin-C compared to Fibronectin. Data are shown as mean \pm SEM. ${ }^{*} p<0.05$; $n=5 /$ group. Scale bar $=50 \mu \mathrm{m}$. 
A

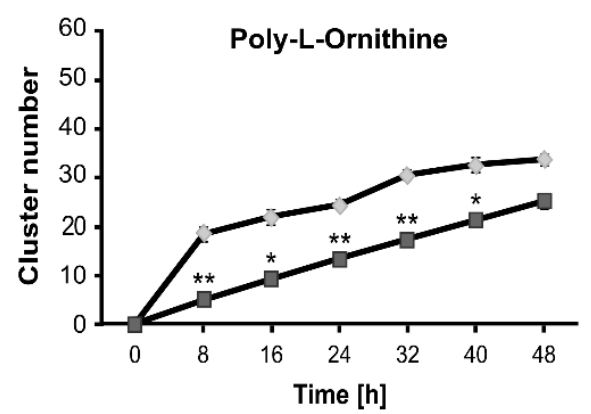

C

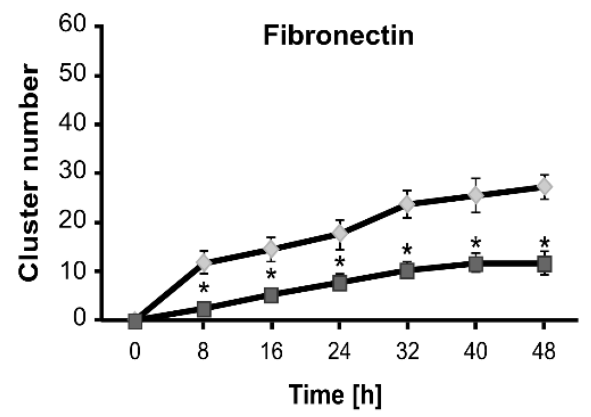

E

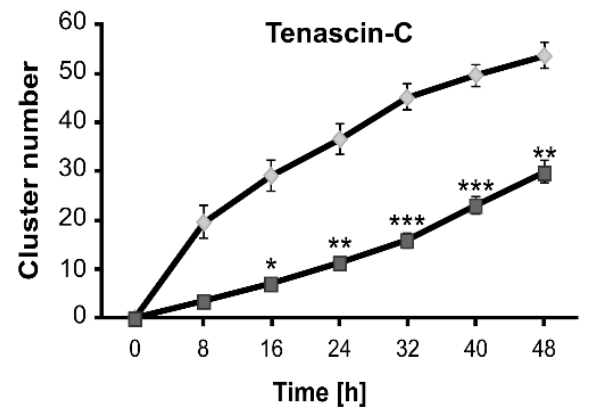

B

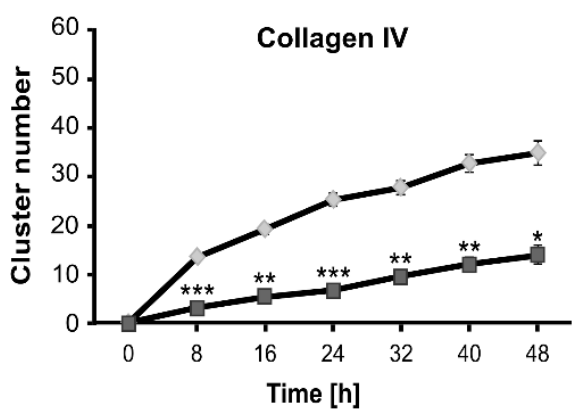

D

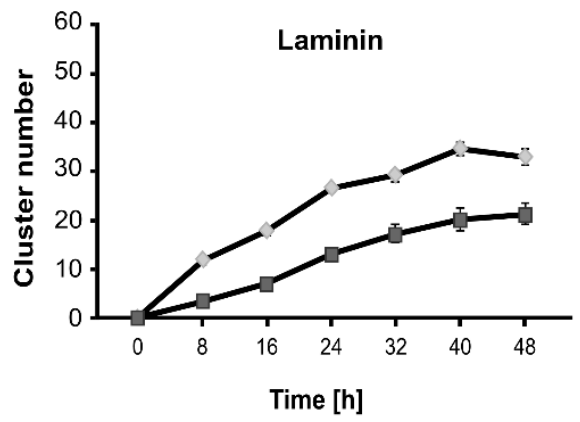

WERI-RB1

WERI-ETOR

Figure 7. Cell cluster number of WERI-RB1 and WERI-ETOR cells cultivated on various ECM substrates via time-lapse microscopy. (A) In comparison to the WERI-RB1 cell line, WERI-ETOR showed a significantly decreased cluster number between 8 and $40 \mathrm{~h}$ when cultivated on Poly-L-Ornithine (non-ECM control). (B) On Collagen IV, WERI-ETOR cells displayed a lower cluster number from 8 to $48 \mathrm{~h}$. (C) Also, on Fibronectin, WERI-ETOR cells displayed a reduced cluster number from 8 to $48 \mathrm{~h}$. (D) In contrast, both RB cell lines exhibited a similar cluster number on Laminin. (E) On Tenascin-C, WERI-ETOR showed a significantly reduced cluster number from 16 to $48 \mathrm{~h}$. Data are shown as mean \pm SEM. ${ }^{*} p<0.05 ;{ }^{* *} p<0.01 ;{ }^{* * *} p<0.001 ; n=3$ /group.

Attached to various substrates, the number of dissociated single WERI-RB1 and WERI-ETOR cells decreased with ongoing time continuously (Figure 6A-C), whereas the number of clusters increased steadily (Figure 6D-E). This general behavior was observed for both cell lines on each ECM substrate. Regarding the cluster number of the WERI-RB1, only Tenascin-C and Fibronectin exhibited a significant impact on cluster formation at $48 \mathrm{~h}$ (Figure 6D). At $48 \mathrm{~h}$, an increased cluster rate was observed on Tenascin-C ( $p=0.02)$, when compared to Fibronectin. WERI-ETOR cells displayed similar cluster rates on all used substrates $(p>0.05$; Figure $6 \mathrm{E}$ ). Taken together, Tenascin- $\mathrm{C}$ significantly promoted cluster formation, while Fibronectin decreased cluster formation of WERI-RB1, but not WERI-ETOR cells.

Next, the cluster rate of WERI-RB1 and WERI-ETOR cells was analyzed in dependence of the ECM substrates (Figure 7A-E).

Overall, the number of clusters was lower in the WERI-ETOR than in the WERI-RB1 cell line. WERI-ETOR cells, cultivated on Poly-L-Ornithine, displayed a significantly decreased cluster formation 
capacity from 8 to $40 \mathrm{~h}(p<0.05$; Figure 7A). Also, on Collagen IV and Fibronectin, the number of WERI-ETOR cell clusters was significantly lower between 8 and $48 \mathrm{~h}$ (both $p<0.05$; Figure 7B-C). In contrast, no difference in the cluster formation rate was found for WERI-RB1 and WERI-ETOR cells when cultivated on Laminin ( $p>0.05$; Figure 7D). On Tenascin-C, a decreased cluster number was observed for WERI-ETOR cells between 16 and $48 \mathrm{~h}(p<0.05$; Figure 7E).

Collectively, these findings indicate that WERI-ETOR cells exhibited a lower cluster forming capacity than WERI-RB1 cells when cultivated on Poly-L-Ornithine and the ECM substrates Collagen IV, Fibronectin, and Tenascin-C.

\section{Discussion}

The mechanisms that contribute to the development of chemoresistance are extremely complex. In recent decades, the ECM, with its diverse functions and complex regulatory influences, has increasingly become a focus of oncological research. The tumor microenvironment, which consists of the tumor's vascular system, the surrounding connective tissue, infiltrating immune cells, and the ECM are important components in the development of chemotherapy resistance, but there is still a lot more to explore [46]. Especially the composition, organization as well as post-translational modifications of the tumor ECM are decisive factors that influence tumor development, growth, angiogenesis, metastasis, and also chemosensitivity [19-24,47].

\subsection{Expression of CSPGs in RB Cells}

Changes of CSPGs have been seen in several solid tumors so far [48-55]. However, currently we do not know the function of CSPG alterations in solid tumors. In our study, we noted a downregulation of the CSPGs BCAN, NCAN, and VCAN, but no different regulation of ACAN mRNA level in WERI-ETOR. As revealed for the WERI-ETOR cell line, our analyses showed a significantly lower expression level of $B C A N$ in Etoposide resistant Y79 cells and a comparable expression level of $A C A N$ in both Y79 cell lines. However, in contrast to the observed downregulation of NCAN and VCAN in the WERI-ETOR cell line, mRNA expression of these proteoglycans was highly upregulated in the Etoposide resistant Y79 cell line. Therefore, we assume that a common alteration in RB seems to be responsible for the significantly lower expression level of $B C A N$ in Etoposide resistant RB cells and comparable level of $A C A N$ in parental and resistant RB cells. In contrast, alterations of NCAN and VCAN seem to be more cell line specific. An up-regulation of CSPGs in tumors and their association with metastasis and malignancy has been demonstrated in different cancer types, such as glioma and lung carcinoma [48-55]. All of this knowledge seems contrary to our findings regarding BCAN and $A C A N$, since it displays the situation in adult tumors. In our study, we investigated a childhood tumor. Considering retinal development, this may explain the meaning of CSPG downregulation in RB. In CNS neurons, glia as well as neural stem cells highly express CSPGs, such as Aggrecan, Brevican, Neurocan, and Versican [56,57]. For all of these CSPGs, a downregulated expression pattern was demonstrated during retinal development $[58,59]$. Therefore, the observed downregulation of $B C A N, N C A N$, and VCAN in Etoposide resistant RB cells contrasts with the expression pattern in adult cancer but might represent the expression pattern in childhood tumors. On the other hand side, BCAN expression has been seen during retinal development as well as in human pluripotent stem cell derived retinal organoids [60]. In this regard, the downregulation of $B C A N$ might be associated with stem cell characteristics in resistant RB cells.

As revealed for the WERI-ETOR cell line, our analyses found a significantly lower expression level of BCAN in Etoposide resistant Y79 cells and a comparable expression level for ACAN in both Y79 cell lines. However, in contrast to the observed downregulation of NCAN and VCAN in the WERI-ETOR cell line, mRNA expression of both proteoglycans was highly upregulated in the resistant Y79 cell line. These expression differences between the two resistant cell lines might point to the fact that expression changes dependent on the intrinsic cellular response of the cell line, rather than Etoposide chemoresistance. As already mentioned above, the prominent upregulation of NCAN and VCAN in 
resistant Y79 cells might also correlate with their role in tumor growth and invasion as it has been demonstrated in glioma and in lung carcinoma [48,49,52-55].

\subsection{Expression of Glycoproteins and Collagen IV in RB Cells}

The interplay between tumor cells and stroma has been suggested to play a key role in tumor progression and sensitivity to chemotherapy [61]. Within our study, we observed a downregulation of COL4A1 in both Etoposide resistant cell lines. As an important component of basement membranes, Collagen IV plays a key role in various tumor types. It stimulates proliferation and migration of pancreatic cancer cells [62]. Additionally, the interaction of pancreatic cancer cells with Collagen IV decreased their sensitivity to cytotoxic drugs and promoted cell proliferation [63]. Furthermore, Collagen IV silencing by small-interfering RNA decreases hepatic metastases formation [64]. In the human retina, it can be found in the Bruch's membrane of the retinal pigment epithelium [65]. Collagen IV is in addition expressed by blood vessels, where it may play a role in neovascularization, blood vessel maturation, and metastasis in RB tumors $[66,67]$. We observed a COL4A1 downregulation in both Etoposide resistant RB cell lines, which seems to be in contrast with the observed upregulation and functional relevance in various tumor types. However, Fang et al. reported that Collagens, including Collagen IV, can be a double-edged sword in tumor progression, both inhibiting and promoting tumor progression at various stages of cancer development [68]. Collagen degradation, e.g. shown in the colorectal adenocarcinoma cell line HCT-8, is of importance for leaving space for ECM remodeling towards tumor metastasis. Skubitz and colleagues demonstrated that Y79 RB cells exhibit a specific adhesion to Fibronectin, but not to Collagen and Laminin [69]. Therefore, our observed downregulation of COL4A1 in both Etoposide resistant $\mathrm{RB}$ cell lines might reflect a functional relevance in the regulation of cellular adhesion due to ECM remodeling after Collagen IV degradation. Recent studies demonstrated the posttranslational alteration of collagens by enzymes like Lysyl oxidases, Focal adhesion kinase, and Prolyl-4-hydroxylases in cancer drug resistance [70-77]. Here, resistance seems to be accomplished by an increased stability of modified helical collagen. Therefore, further analyses of posttranslational collagen alterations should be performed in RB chemotherapy resistance investigations.

Expression of FN1 was also reduced in WERI-ETOR, while resistant Y79 cells displayed only a trend towards a reduced but comparable expression level in comparison to the sensitive Y79 cells. Tumor cell migration, invasion and metastasis are essentially influenced by Fibronectin-Integrin interaction and alterations in the tumor microenvironment [78-82]. Especially in breast cancer, increased amounts of Fibronectin activate the FAK/ILK/ERK/PIK/NK-KB signaling pathway and hereby mediate an up-regulation of MMP-2 and -9 [83]. Taken together, ECM alterations are seen in tumor metastasis, but not in RB chemotherapy resistance.

LAMA1 expression was downregulated in resistant WERI-ETOR. However, in contrast to the findings in the resistant WERI-ETOR cell line, expression of $L A M A 1$ was significantly upregulated in the resistant $Y 79$ cell line.

Therefore, our data suggest that COL4A1 and probably also FN1 are associated with chemotherapy resistance in $\mathrm{RB}$, while $L A M A 1$ alterations seem to be $\mathrm{RB}$ cell line specific.

\subsection{Expression of Tenascin-C and Tenascin-R in RB Cells}

The importance of Tenascins in retina development and diseases has been postulated $[84,85]$. In addition, glioma malignancy grade, and poor prognosis correspond with a high expression of Tenascin-C [86-88]. Furthermore, various studies explored Tenascin- $C$ as trigger for cancer drug resistance [89-92]. A study on human colon carcinoma tissue demonstrated a link between Tenascin-C upregulation and cancer cell invasion [93].

In our study, we noted a significant downregulation of TNC expression in WERI-ETOR cells. While TNC expression was comparable in the sensitive and resistant Y79 cell lines. Analysis on protein level, on the other side, did not show differences in the Tenascin-C concentration in 
WERI-RB1 and WERI-ETOR cells. Additionally, a higher cell death rate was observed for WERI-ETOR on Tenascin-C coating. Therefore, we assume, that expression and protein level of Tenascin- $C$ seem to be similar in a chemotherapy resistant and sensitive situation in RB but may lead to malignancy and chemotherapy resistance through unknown posttranslational alterations in this matrix protein and/or an isoform-dependent regulation.

In the present study, we described a massive downregulation of TNR in WERI-ETOR and resistant Y79 RB cells. Inhibiting properties of Tenascin-R were described in regard to adhesion of mesenchymal and neural cells on Fibronectin, whereas the role of Tenascin-R has barely been investigated in cancer $[87,94,95]$. Our data indicate a statistically significantly lower level of clustering for WERI-ETOR on Fibronectin in comparison to WERI-RB1. This might be triggered by downregulation of TNR expression.

\subsection{Expression of MMPs and TIMPs in RB Cells}

In the present study, we noted a dramatic downregulation of $M M P 2, M M P 7$, as well as $M M P 9$ expression in WERI-ETOR. A statistically significant downregulation of MMP2 expression was confirmed in resistant Y79 cells. While analysis on protein level for pro- and active-MMP-2 in WERI-RB1 and WERI-ETOR did not show any striking differences. Previous studies by other research groups, on the other hand, observed a high expression of MMP-2 and MMP-9 in correlation with a higher clinical grading of RB tissue [96,97]. Also, inhibition of MMP-2 and MMP-9 led to a decreased cellular migration and angiogenesis in in vitro models of RB [98]. In contrast, high levels of MMP2 were found to be associated with a better chemotherapy response in ovarian cancer tissue [99]. Therefore, downregulation of MMP2 may lead to chemotherapy resistance in RB via an unknown mechanism. Nevertheless, on protein level MMP-2 was not reduced in resistant WERI-ETOR cells, which should be investigated further.

Aditi and colleagues investigated MMP-2, MMP-9, TIMP-1, and TIMP-2 expression in RB tissue via immunohistochemical staining and immunoblotting [97]. Upregulation of MMPs and TIMPs correlated with a higher clinical RB malignancy scoring and therefore with metastasis. Contradictory to these data, our results did not show differences in TIMP1 expression between both WERI cell lines, but a downregulation of TIMP2 expression in chemotherapy resistant WERI-ETOR cells. Expression analysis of Y79 confirmed the downregulation of TIMP2 but revealed an upregulation of TIMP1 in resistant Y79 cells. On the one hand, different reports revealed the complexity of the MMP and TIMP interaction on ECM in cancer. A Bcl-2 mediated anti-apoptotic effect was seen for TIMPs in tumor cells [100]. On the other hand, TIMPs inhibited tumor invasion and metastasis [101]. TIMP-2 upregulation was linked to metastasis via MMP-2 inactivation in nasopharyngeal carcinoma [102]. Additionally, a high ratio of MMP-9 to TIMP-2, implicating that a higher TIMP-2 level leads to drug resistance, was beneficial for the treatment of metastatic renal cell carcinoma [103]. Furthermore, higher tissue levels of TIMP-2 marked a favorable prognosis in ovarian cancer [104]. In this line, therapeutic upregulation of TIMP-2 reduced the invasiveness of a metastatic breast cancer cell line [105]. TIMP-2 might have the same function in RB. In summary, the interplay between MMPs and TIMPs seems to be rather complex in RB metastasis, but TIMP-2 downregulation might lead to metastasis and chemotherapy resistance in RB.

\subsection{Integrin Expression in RB Cells}

In our study, we observed a downregulation of ITGA4, ITGA5, and ITGB1 expression in WERI-ETOR, but only ITGA5 expression downregulation was confirmed in resistant Y79 cells. Interestingly, $\alpha 5$-Integrin has been described as a potential suppressor for tumor metastasis in a non-metastatic breast cancer cell line, whereas $\alpha 6$-Integrin had opposed characteristics in a metastatic breast cancer cell line and may promote metastasis [106]. In addition, a Fibronectin-dependent enhanced expression of $\alpha 5 \beta 1$ Integrin is associated with ovarian cancer metastasis [107]. Some specific Integrins were also described as tumor suppressors, especially $\alpha 5$ Integrin has been reported to inhibit tumor cell growth through their effects on cell-cycle-regulating proteins and proteins responsible for 
DNA repair [106,108]. Therefore, it could be possible that the observed downregulation of $\alpha 5$ Integrin in resistant $\mathrm{RB}$ cells might be associated with chemotherapy resistance by promoting cell cycle progression and by enhancing the repair of DNA double-strand breaks caused by various chemotherapeutic agents including Etoposide. Also, an upregulation of $\alpha 5 \beta 1$ compromised p53 induced chemotherapy sensitivity in high grade glioma [109]. However, $\alpha 5 \beta 1$ Integrin promotes invasive tumor protrusions by promoting joint Integrin/Receptor tyrosine kinase signaling [110,111]. In summary, we assume that downregulation of ITGA5 expression in RB might be associated with a higher metastasis rate and chemotherapy resistance. However, this finding needs to be investigated in more detail.

\subsection{Expression of RPTP $\beta / \zeta$ in $R B$ Cells}

During adolescence, the RPTP $\beta /$ /isoform Phosphacan is expressed in Müller cells, while RPTP $\beta / \zeta_{\text {long }}$ is barely expressed in the adult retina [58,85]. In our study, using a set of various primers, we analyzed $R P T P \beta / \zeta_{\text {long }}, R P T P \beta / \zeta_{\text {short }}$, and Phosphacan in WERI-RB1. In general, the $R P T P \beta / \zeta$ isoforms were, if ever, only slightly expressed in WERI-ETOR cells. As a functional binding partner of the vascular endothelial growth factor, $R P T P \beta / \zeta$ is postulated to be an angiogenesis promoting factor, a potential hallmark for metastasis [112]. Interestingly, in concordance with our results, Diamantopoulou and colleagues demonstrated that a loss of $R P T P \beta / \zeta$ initiates epithelial-to-mesenchymal transition and leads to metastasis in prostate cancer [113]. Therefore, our observed downregulation or loss of $R P T P \beta / \zeta$ isoforms may indicate an epithelial-to-mesenchymal transition towards a chemotherapy resistance in RB.

Phosphacan $/ \mathrm{RPTP} \beta / \zeta$ is an important and well described binding partner and receptor of the ECM glycoprotein Tenascin-C $[43,44]$. Furthermore, Tenascin-C directly interacts with the CSPG Neurocan [114] and Integrin receptors [115]. Additionally, it is cleaved by various MMPs [116]. Due to these facts, it was interesting that we observed a prominent downregulation of all RPTP $\beta / \zeta$ isoforms in resistant WERI-ETOR cells. This result could also point to reduced interacting ECM network between Tenascin-C and the CSPGs Phosphacan and Neurocan, the RPTP $\beta / \zeta$ receptor as well as MMPs. However, there is still a lot to explore and discover, before understanding the interaction of the ECM network in RB.

\subsection{ECM Influence on the Apoptotic Rate of RB Cells}

In this study, we investigated the rate of apoptotic RB cells by cleaved Caspase 3 immunostaining. A significantly higher apoptotic rate was present in WERI-RB1 cultivated on Fibronectin in comparison to all other tested substrates. Interestingly, a significantly increased apoptotic cell number was seen in WERI-ETOR in comparison to WERI-RB1 cells after cultivation on Tenascin-C. However, one should consider that the intrinsic apoptosis rate of WERI-ETOR is higher, as seen on the Poly-Ornithine condition. Different studies verified a correlation between Tenascin-C expression and prognosis in different cancer types, like chondrosarcoma as well as prostate and breast cancer [91,117-119]. On the one hand, a promoting effect on apoptosis was reported for Fibronectin in prostate cancer cells [120]. On the other hand, Fibronectin obtained an anti-apoptotic effect via Bcl-2 (B-cell lymphoma) in cancer [121]. Therefore, especially Fibronectin alterations might lead to different malignancy and chemotherapy resistance in RB.

\subsection{ECM Influence on the Proliferation Rate of RB Cells}

In the present study, we investigated the effect of Poly-L-Ornithine, Collagen IV, Fibronectin, Laminin, and Tenascin-C on WERI-RB1 and WERI-ETOR proliferation. A significantly lower proliferation of WERI-ETOR on Fibronectin in comparison to Tenascin-C coating was only detected by time-lapse video microscopy, but not by phospho Histone $\mathrm{H} 3$ and Hoechst co-staining. Previous studies demonstrated a positive effect of Fibronectin and Collagen IV on lens epithelial cell proliferation [122]. In accordance with these findings, Illario and colleagues noted an increased mitosis rate for thyroid cells cultivated on Fibronectin, including cell adhesion and spreading [123]. Interestingly, Orend et al. observed an inhibitory effect of Tenascin-C on Fibronectin promoted proliferation in fibroblasts [124]. 
In sum, our data revealed a higher proliferation rate of WERI-ETOR on Tenascin-C in comparison to Fibronectin, which further supports the idea of a switch from a Fibronectin dominated chemotherapy sensitive ECM environment to a Tenascin-C dominated chemotherapy resistant ECM environment.

\subsection{ECM Influence on Cluster Formation of RB Cells}

Circulating tumor cell clusters were observed in the peripheral blood of colorectal cancer patients [125]. The same effects were seen in circulating breast tumor cells [126]. In contrast to metastatic data, our results indicate a higher number of clusters in WERI-RB1. This phenomenon might be explained by the different nature of RB tumors, including RB protein loss, in comparison to previously mentioned, mostly carcinoma, tumors. Hence this should be further investigated. Interestingly, WERI-ETOR cells displayed a reduced cluster formation capacity on Tenascin-C. Indeed, Tenascin-C can exhibit repulsive properties, which may lead to a reduced aggregate formation. In this regard, a counterbalancing anti-adhesive effect of Tenascin-C through Fibronectin expression was reported in endothelial cells [127].

\subsection{Limitations and Future Perspectives of the Study}

The aim of the present study was to explore the composition of the ECM and its alteration in RB chemotherapy resistance. In our study, most experiments have been performed in the RB cell lines WERI-RB1 and WERI-ETOR. We performed in vitro proliferation, cell death and adhesion analyses in both cell lines. Additionally, both cell lines were tested in regard to the mRNA expression of various ECM molecules as well as several modulating enzymes and receptors. Here, we found mRNA differences between WERI-RB1 and WERI-ETOR, which might display the situation in human RB. Also, exemplary protein analyses via Western blot for TNC and MMP-2 were performed in WERI-RB1 and WERI-ETOR cell lines. As we found no differences for these two proteins and other proteins were not tested so far, future analyses should uncover possible protein alterations in both RB cell lines. In order to evaluate mRNA expression in two independent cell lines, analyses regarding the expression of the CSPGs $A C A N, B C A N, N C A N$, and $V C A N$, the glycoproteins LAMA1, FN1, and TNC and TNR, MMP2, MMP7, MMP9, TIMP1, and TIMP2 and the integrin receptor subunits ITGA4, ITGA5, as well as ITGB1 were also performed in Y79 and resistant Y79 RB cells.

A study limitation was that many of the mRNA results need to be confirmed by Western blotting. In a follow up project, experiments should focus on protein levels of both Y79 cell lines. A further limitation of this study was that most data were only from one cell line and its subclone (WERI-RB1 and WERI-ETOR). Therefore, future studies should also focus on in vitro analyses in Y79 cells.

\section{Materials and Methods}

\subsection{Cultivation and Authentication Verification of Human RB Cell Lines}

The Etoposide sensitive and resistant RB cell lines WERI-RB1 and Y79 were cultured as described previously [36-38]. Briefly, cells were cultured in T75 flasks (Greiner, Kreuzmünster, Austria) in Dulbecco's Modified Eagle's Media (DMEM) supplemented with 15\% fetal calf serum (FCS), $1 \%$ penicillin and streptomycin, $4 \mathrm{mM}$ L-glutamine, $50 \mu \mathrm{M} \beta$-mercaptoethanol and $10 \mu \mathrm{g} / \mathrm{mL}$ insulin (all Sigma-Aldrich, St. Louis, MO, USA) at $37^{\circ} \mathrm{C}$ and $10 \% \mathrm{CO}_{2}$.

Identities of all RB cell lines were verified by DNA fingerprinting and profiling using eight different and highly polymorphic short tandem repeat (STR) loci (Leibniz-Institute DSMZ GmbH, Braunschweig). Generated STR profiles of cell lines showed a full match of the respective parental reference STR profiles as indicated by a search of the cell bank databases ATCC (Manassas, VA, USA), JCRB (Osaka, Japan) and RIKEN (Ibaraki, Japan), KCLB (Seoul, Korea), as well as DSMZ (Braunschweig, Germany). Also, purity of cell lines was proven by analyses of mitochondrial DNA sequences from mouse, rat or Chinese and Syrian hamster cells. Analyses, with a detection limit of 1:10 
the absence of any mitochondrial sequences from foreign species. Hence, the origin and purity of the human RB cell lines was determined.

\subsection{Cultivation of the Human Glioblastoma Cell Line U-251-MG and Purification of Human Tenascin-C}

For the purification of human Tenascin-C, the cell line U-251-MG was cultured in T250 flasks (Thermo Fischer Scientific, Breda, Netherlands) in Minimum Essential Medium $\alpha$ with GlutaMAX I ( $\alpha$-MEM; Thermo Fischer Scientific) supplemented with 10\% FCS and $0.1 \%$ gentamycin (Roth, Karlsruhe, Germany) at $37^{\circ} \mathrm{C}$ and $6 \% \mathrm{CO}_{2}$. After 7 days, the supernatant was collected. For Tenascin-C purification, affinity chromatography was performed using the monoclonal antibodies 608 and $19 \mathrm{H} 12$ as described previously [86].

\subsection{Cell Proliferation and Cluster Formation Analyses Via Time-Lapse Video Microscopy}

In order to analyze the proliferation and cluster formation behavior of the WERI cells on different ECM substrates, WERI-RB1 and WERI-ETOR cells were dissociated in $1 \mathrm{~mL}$ Trypsin/EDTA (Thermo Fisher Scientific) at $37^{\circ} \mathrm{C}$ for $5 \mathrm{~min}$. Thereafter, enzymatic dissociation of cells was stopped using an equal amount of Ovomucoid containing $1 \mathrm{mg} / \mathrm{mL}$ soybean trypsin inhibitor in L-15 medium (both Sigma-Aldrich), $40 \mu \mathrm{g} / \mathrm{mL}$ DNase I (Worthington, Lakewood, USA), and $50 \mu \mathrm{g} / \mathrm{mL}$ bovine serum albumin (BSA; Sigma-Aldrich). Following resuspension in fresh serum-free culture medium, cell numbers were determined in a Neubauer counting chamber (Brand, Wertheim, Germany). 24-well-dishes (Thermo Fisher Scientific) were pre-coated with Poly-L-Ornithine (10 $\mu \mathrm{g} / \mathrm{mL}$; Sigma-Aldrich) in $\mathrm{H}_{2} \mathrm{O}$. Next, wells were coated with ECM substrates, namely human Fibronectin $(10 \mu \mathrm{g} / \mathrm{mL}$; Corning Inc., Wiesbaden, Germany), mouse Laminin (10 $\mathrm{gg} / \mathrm{mL}$; Corning Inc.), human Collagen IV $(10 \mu \mathrm{g} / \mathrm{mL}$; Sigma-Aldrich $)$, or human Tenascin-C $(50 \mu \mathrm{g} / \mathrm{mL})$ in $1 \times$ PBS. $3 \times 10^{4}$ dissociated cells were seeded in $500 \mu \mathrm{L}$ serum free culture medium per well. Cells were documented via time-lapse video microscopy (Axiovert 200M; Zeiss, Jena, Germany) in a heated chamber at $37^{\circ} \mathrm{C}$ and $10 \% \mathrm{CO}_{2}$ for $48 \mathrm{~h}$. An image of each well was recorded every $8 \mathrm{~min}$ and combined for a time-lapse video. At 0,8 , $16,24,32,40$, and 48 hours after plating, we counted the number of single cells as well as cell clusters, defined as 3 or more cells.

\subsection{RNA Isolation and cDNA Synthesis}

To obtain mRNA, $5 \times 10^{6}-1 \times 10^{7}$ Etoposide resistant and sensitive WERI, Etoposide resistant and sensitive and Y79 RB cells or U-251-MG cells were snap frozen in liquid nitrogen. Total RNA extraction was performed with the Gene Elute Mammalian Total RNA Miniprep Kit (Sigma-Aldrich) following the manufacturer's instructions. Purity and concentration of RNA was analyzed using a BioSpectrometer (Eppendorf, Hamburg, Germany). For cDNA synthesis, $1 \mu \mathrm{g}$ RNA was reverse-transcripted with the First Strand cDNA Synthesis Kit using random hexamer primers (Thermo Fisher Scientific).

\subsection{Quantitative Real-Time PCR Analyses (RT-qPCR)}

RT-qPCR analyses were performed using the FastStart essential DNA green master mix in a Light Cycler 96 (Roche Applied Science, Mannheim, Germany). Reaction conditions were as follows: $10 \mathrm{~min}$ at $95{ }^{\circ} \mathrm{C}$ (pre-incubation), followed by $10 \mathrm{sec}$ at $95{ }^{\circ} \mathrm{C}, 30 \mathrm{sec}$ at $60{ }^{\circ} \mathrm{C}$, and $10 \mathrm{sec}$ at $72{ }^{\circ} \mathrm{C}$ for 45 cycles (amplification), $10 \mathrm{sec}$ at $95^{\circ} \mathrm{C}, 60 \mathrm{sec}$ at $65^{\circ} \mathrm{C}$, and $1 \mathrm{sec}$ at $97^{\circ} \mathrm{C}$ (melting curve analyses) and $30 \mathrm{sec}$ at $37^{\circ} \mathrm{C}$ (cool down period). Primer pairs for RT-qPCR (Sigma-Aldrich) were designed using the ProbeFinder Assay Design Center (Roche Applied Science; Table 1). Primer efficiency of each primer was calculated based on a cDNA dilution series of $5 \mathrm{ng}$ to $125 \mathrm{ng}$. The housekeeping genes $\beta$-Actin (ACTB), Glyceraldehyde 3-phosphate dehydrogenase (GAPDH), and S18 (RBPS18) were used for normalization and relative quantification. 
Table 1. List of primer pairs used for RT-qPCR analyses of RB cell lines. For relative quantification of mRNA levels, $\beta$-Actin (ACTB), Glyceraldehyde 3-phosphate dehydrogenase (GAPDH), and S18 (RBPS18) served as housekeeping genes. For each gene, the primer sequence and predicted amplicon size is indicated. Abbreviations: $\mathrm{bp}$-base pairs, for-forward, rev-reverse.

\begin{tabular}{|c|c|c|c|c|}
\hline Primer Name & Gene & Primer Sequence & Accession Number & Product Size (bp) \\
\hline Aggrecan for & \multirow{2}{*}{$A C A N$} & tcaccagtgaggacctcgt & NM_001135.3 & \multirow{2}{*}{84} \\
\hline Aggrecan rev & & ggcggtagtggaagacgac & NM_013227.3 & \\
\hline$\beta$-Actin for & \multirow{2}{*}{$A C T B$} & ccaaccgcgagaagatga & \multirow{2}{*}{ NM_001101.3 } & \multirow{2}{*}{97} \\
\hline$\beta$-Actin rev & & ccagaggcgtacagggatag & & \\
\hline Brevican for & \multirow{2}{*}{$B C A N$} & tggaagctccactccagaa & \multirow{2}{*}{ NM_021948.4 } & \multirow{2}{*}{76} \\
\hline Brevican rev & & cggtaccatggattgtgtttc & & \\
\hline Collagen IV for & \multirow{2}{*}{ COL4A1 } & gggagaaaagggtgaagca & \multirow{2}{*}{ NM_001845.5 } & \multirow{2}{*}{72} \\
\hline Collagen IV rev & & ccaaaggtcctgtgcctataa & & \\
\hline \multirow{3}{*}{ Fibronectin for } & \multirow{5}{*}{ FN1 } & \multirow{3}{*}{ cttccacaggaggcctacac } & NM_212482.1 & \multirow{5}{*}{114} \\
\hline & & & NM_002026.2 & \\
\hline & & & NM_212478.1 & \\
\hline \multirow{2}{*}{ Fibronectin rev } & & \multirow{2}{*}{ cgcaaaatatgctggaacttt } & NM_212476.1 & \\
\hline & & & NM_212474.1 & \\
\hline \multirow{2}{*}{ GAPDH for } & \multirow{4}{*}{ GAPDH } & \multirow{2}{*}{ tccactggcgtcttcacc } & NM_001289746.1 & \multirow{4}{*}{114} \\
\hline & & & NM_001289745.1 & \\
\hline \multirow{2}{*}{ GAPDH rev } & & \multirow{2}{*}{ ggcagagatgatgaccctttt } & NM_001256799.2 & \\
\hline & & & NM_002046.5 & \\
\hline$\alpha 4$-Integrin for & \multirow{2}{*}{ ITGA4 } & gatgaaaatgagcctgaaacg & \multirow{2}{*}{ NM_000885.4 } & \multirow{2}{*}{80} \\
\hline$\alpha 4$-Integrin rev & & gccatactattgccagtgttga & & \\
\hline$\alpha 5$-Integrin for & \multirow{2}{*}{ ITGA5 } & cccattgaatttgacagcaa & \multirow{2}{*}{ NM_002205.2 } & \multirow{2}{*}{92} \\
\hline$\alpha 5$-Integrin rev & & tgcaaggacttgtactccaca & & \\
\hline$\beta 1$-Integrin for & & cgatgccatcatgcaagt & NM_002211 & \\
\hline$\beta 1$-Integrin rev & & acaccagcagccgtgtaac & NM_133376 & r \\
\hline$\alpha 1$-Laminin for & & aggatgacctccattctgactt & NIM 0055502 & \\
\hline$\alpha 1-L a m i n i n$ rev & LRIV1R1 & ccttacatgggcactgacct & NVIV__000009.0 & ou \\
\hline & & & NM_001302510.1 & \\
\hline$M M P-2$ for & & ctacgaccgcgacaagaagt & NM_001302509.1 & \\
\hline & $M M P 2$ & & NM_001302508.1 & 114 \\
\hline$M M P_{2} 2$ rey & & agttcccaccaacagtgoac & NM_001127891.2 & \\
\hline IVIVIT-Z IEV & & 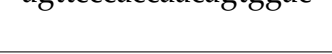 & NM_004530.5 & \\
\hline$M M P-7$ for & $M M P 7$ & gctgacatcatgattggcttt & NM 0024233 & 113 \\
\hline$M M P-7$ rev & 年 & tctcctccgagacetgtcc & - & 10 \\
\hline$M M P-9$ for & $M M D Q$ & gtaccacggccaactacgac & NM 0040942 & \\
\hline$M M P-9$ rev & 10110110 & gccgtcctgggtgtagagt & 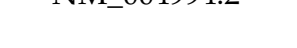 & 17 \\
\hline
\end{tabular}


Table 1. Cont.

\begin{tabular}{|c|c|c|c|c|}
\hline Primer Name & Gene & Primer Sequence & Accession Number & Product Size (bp) \\
\hline Neurocan for & \multirow{2}{*}{ NCAN } & aggggttcggagctatgg & \multirow{2}{*}{ NM_004386.2 } & \multirow{2}{*}{95} \\
\hline Neurocan rev & & ggcccacgtagaagacctc & & \\
\hline S18 for & \multirow{2}{*}{ RPS18 } & cttccacaggaggcctacac & \multirow{2}{*}{ NM_022551.2 } & \multirow{2}{*}{82} \\
\hline S18 rev & & cgcaaaatatgctggaacttt & & \\
\hline TIMP-1 for & \multirow{2}{*}{ TIMP1 } & agtggcactcattgcttgtg & \multirow{2}{*}{ NM_003254.2 } & \multirow{2}{*}{104} \\
\hline TIMP-1 rev & & ggactggaagcccttttca & & \\
\hline TIMP-2 for & \multirow{2}{*}{ TIMP2 } & gaagagcctgaaccacaggt & \multirow{2}{*}{ NM_003255.4 } & \multirow{2}{*}{85} \\
\hline TIMP-2 rev & & cggggaggagatgtagcac & & \\
\hline Tenascin-C for & \multirow{2}{*}{ TNC } & gtctccagcctgccacag & \multirow{2}{*}{ NM_002160.3 } & \multirow{2}{*}{82} \\
\hline Tenascin-C rev & & cgcctttccagccaggttc & & \\
\hline Tenascin- $R$ for & \multirow{2}{*}{ TNR } & agtgacctctgagcccattg & \multirow{2}{*}{ NM_003285.2 } & \multirow{2}{*}{61} \\
\hline Tenascin- $R$ rev & & gatgtcttttgggggatcaa & & \\
\hline Versican for & \multirow{2}{*}{$V C A N$} & tcccaggaaacttacgatg & \multirow{2}{*}{ NM_004385.4 } & \multirow{2}{*}{70} \\
\hline Versican rev & & ggggacagtgaggtgggaa & & \\
\hline
\end{tabular}

\subsection{Semi-Quantitative Reverse-Transcription PCR Analyses (RT-PCR)}

By combining different primer pairs, modified according to Norman et al., unique $R P T P \beta / \zeta$ (PTPRZ1) isoforms were analyzed via semi-quantitative RT-PCR (Table 2) [45]. RT-PCR using CP and EC primer pairs was performed with Taq DNA Polymerase (Sigma-Aldrich). For the amplification of long products with TEC primers, the GoTaq Long PCR Master Mix (Promega, Mannheim, Germany) was used. RT-PCR was performed in a Mastercycler Gradient (Eppendorf, Hamburg, Germany). RT-PCR reaction conditions for $\mathrm{CP}$ and EC primers were as follows: 5 min at $94{ }^{\circ} \mathrm{C}$ (pre-denaturation), followed by 28 cycles (ACTB) to 38 cycles (PTPRZ1 isoforms) of $30 \mathrm{sec}$ at $94{ }^{\circ} \mathrm{C}$ (denaturation), $30 \mathrm{sec}$ at $60^{\circ} \mathrm{C}$ (annealing), and $30 \mathrm{sec}$ at $72{ }^{\circ} \mathrm{C}$ (elongation). For RT-PCR using TEC primers the following conditions were used: $2 \mathrm{~min}$ at $94^{\circ} \mathrm{C}$ (pre-denaturation), 40 cycles of $30 \mathrm{sec}$ at $94{ }^{\circ} \mathrm{C}$ (denaturation), $30 \mathrm{sec}$ at $60{ }^{\circ} \mathrm{C}$ (annealing), and $3 \mathrm{~min}$ at $65^{\circ} \mathrm{C}$ (elongation). The products were separated in $1.5 \%$ agarose gels.

Table 2. List of primer pairs used for semi-quantitative RT-PCR analyses of $R P T P \beta / \zeta$ isoforms in WERI-RB1 and WERI-ETOR cells. For quantification of RPTP $\beta / \zeta$ (PTPRZ1) mRNA levels, ACTB served as a housekeeping gene. For each primer, the primer sequence and the predicted amplicon size is indicated. Abbreviations: $\mathrm{bp}$-base pairs, for-forward, rev-reverse.

\begin{tabular}{|c|c|c|c|c|}
\hline Primer Name & Gene & Primer Sequence & Accession Number & Amplicon Size (bp) \\
\hline$\beta$-Actin for & \multirow{2}{*}{ AСТB } & tgacggggtcacccacactgtgcccatcta & \multirow{2}{*}{ NM_001101.3 } & \multirow{2}{*}{661} \\
\hline$\beta$-Actin rev & & ctagaagcatttgcggtggacgatggaggg & & \\
\hline $\mathrm{CP} R P T P \beta / \zeta$ for & \multirow{6}{*}{ PTPRZ1 } & agtgtgcaagtgcttgcctat & XM_005250519.1 & \multirow{2}{*}{555} \\
\hline $\mathrm{CP} R P T P \beta / \zeta$ rev & & tgcagaatagtcactctgctg & XM_017012477.1 & \\
\hline $\mathrm{EC} R P T P \beta / \zeta$ for & & tgcctacttcccaactgag & \multirow{2}{*}{ NM_002851.2 } & \multirow{2}{*}{509} \\
\hline $\mathrm{EC} R P T P \beta / \zeta$ rev & & cagcatgagtagtggac & & \\
\hline TEC RPTP $\beta / \zeta$ for & & tgcctacttcccaactgag & \multirow{2}{*}{ NM_001206839.1 } & 369 \\
\hline TEC RPTP $\beta / \zeta$ rev & & attgctccgacatcatctg & & 2949 \\
\hline
\end{tabular}




\subsection{Immunocytochemistry}

For immunocytochemical staining, $15 \times 10^{3}$ dissociated cells were seeded on Poly-L-Ornithine pre-coated 4-well-dishes ( 3 wells/condition; Thermo Fisher Scientific) and incubated for 2 div. After cultivation, cells were washed and blocked with prewarmed Krebs' solution-Ringer's solution-HEPES buffer (KRH/A; $125 \mathrm{mM} \mathrm{NaCl}, 4.8 \mathrm{mM} \mathrm{KCl}, 1.3 \mathrm{mMCaCl}_{2} \cdot 2 \mathrm{H}_{2} \mathrm{O}, 1.2 \mathrm{mM} \mathrm{MgSO}_{4} \cdot 7 \mathrm{H}_{2} \mathrm{O}$, $1.2 \mathrm{mM} \mathrm{KH}_{2} \mathrm{PO}_{4}, 5.6 \mathrm{mM}$ D-glucose, $25 \mathrm{mM}$ HEPES and 0.1\% BSA). After washing twice in $\mathrm{KRH}$, cells were fixed with $4 \%$ paraformaldehyde (PFA) in 1x PBS at room temperature (RT) for 10 min and then washed twice in PBT1 (1x PBS, 0.1\% Triton-X-100, 0.1\% BSA). The cells were stained using anti-phospho Histone H3 (proliferative M-phase cells; PH3; rabbit, 1:100, Merck Millipore, Darmstadt, Germany) and anti-cleaved Caspase 3 antibodies (apoptotic cells; rabbit, 1:200, Sigma-Aldrich). To visualize F-Actin (Sigma-Aldrich), Phalloidin staining (1:100) was performed. Therefore, primary antibody/Phalloidin was diluted in PBT1 and this solution was applied to the cells. Following incubation for at RT $1 \mathrm{~h}$, cells were washed twice with PBS/A (1× PBS, 0.1\% BSA). Species-specific Cy/Cy3-coupled secondary antibodies (all Dianova GmbH, Hamburg, Germany), diluted 1:300 in PBS/A, were applied for at RT $1 \mathrm{~h}$. To stain cell nuclei, the secondary antibody solution was supplemented with Hoechst (1:100.000; Hoechst 33258, Sigma-Aldrich). After two washing steps with $1 \times$ PBS, cells were mounted in $1 \times$ PBS/glycerol and covered with a glass coverslip. Stained cells were documented via an inverted fluorescence microscope (Axioplan 2; Zeiss). For each condition, 3 images/well were taken with 300-500 cells/visual field. For each staining and condition at least 3 independent experiments were performed. The counted cells were cultivated in 3 wells of a 4-well-dish with a negative control.

\subsection{Protein Lysis and Western Blot}

WERI-RB1, WERI-ETOR and U-251-MG cells $\left(5 \times 10^{6}-1 \times 10^{7}\right)$ were homogenized in $100 \mu \mathrm{L}$ lysis buffer (10 mM Tris base, $1 \mathrm{mM}$ EDTA, $0.5 \mathrm{mM}$ EGTA, 1\% (v/v) Triton-X-100, 0.1\% (v/v) SDS, 0.1\% $(v / v)$ sodium deoxycholate, $140 \mathrm{mM} \mathrm{NaCl})$ on ice for $1 \mathrm{~h}$. Afterwards, proteins were centrifuged at $14,000 \times \mathrm{g}$ for $10 \mathrm{~min}$ at $4{ }^{\circ} \mathrm{C}$. The Pierce ${ }^{\mathrm{TM}}$ BCA Protein Assay Reagent kit (Thermo Fisher Scientific) was used according to manufacturer's instructions to determine the protein concentration in the supernatant. Protein samples $(20 \mu \mathrm{g})$ were diluted in $4 \mathrm{x}$ loading buffer ( $250 \mathrm{mM}$ Tris base, $40 \%$ glycerin, $20 \% \beta$-mercaptoethanol, $20 \%$ SDS and $0.03 \mathrm{mM}$ bromophenol blue) and denaturized at $95{ }^{\circ} \mathrm{C}$ for 5 min. Proteins were separated using 4-10\% polyacrylamide gradient gels. By Western blotting, proteins were transferred to polyvinylidene difluoride (PVDF) membranes (Roth, Karlsruhe, Germany). Membranes were blocked in TBST blocking solution ( $5 \% w / v$ milk powder in Tris-buffered saline (TBS) and $0.05 \%$ Tween-20) at RT for $1 \mathrm{~h}$ and then incubated with primary antibody in blocking solution overnight at $4{ }^{\circ} \mathrm{C}$. In order to detect Tenascin-C, a polyclonal anti-rabbit antibody was used in a dilution of 1:5,000 [128]. MMP-2 protein was analyzed by a rabbit antibody (H-76, 1:1,000, Santa Cruz Biotechnology, CA, USA). The housekeeping protein $\alpha$-Tubulin was detected using a monoclonal anti-mouse antibody (DM1A, 1:10,000, Sigma-Aldrich). After antibody incubation, membranes were washed in TBST for $15 \mathrm{~min}$ and incubated with species-specific goat horseradish peroxidase (HRP) coupled secondary antibodies (1:5,000-1:10,000, Dianova $\mathrm{GmbH})$ in blocking solution for $1 \mathrm{~h}$ at RT. Afterwards, membranes were washed in TBST for $10 \mathrm{~min}$ and TBS for $15 \mathrm{~min}$ at RT. To detect protein bands, the two solutions of the SuperSignal ${ }^{\mathrm{TM}}$ West Pico chemiluminescence kit (Thermo Fisher Scientific) were mixed 1:1 and added to the PVDF membrane. After incubation at RT for $5 \mathrm{~min}$, chemiluminescence was detected and documented in a detection chamber (MicroChemi Chemilumiscence Reader, Biostep, Burkhardtsdorf, Germany). The intensity of TNC and pro- and active-MMP-2 protein bands was measured using TotalLab Quant software (TotalLab, Newcastle upon Tyne, UK) and normalized against the $\alpha$-tubulin band intensity. 


\subsection{Statistical Analyses}

Data of RT-qPCR are presented as median \pm quartile + maximum/minimum and were analyzed by the pairwise fixed reallocation and randomization test (REST 2009 released Qiagen, [129]). RT-PCR data are shown as mean \pm standard deviation (SD). Immunocytochemical, time-lapse video microscopy and Western blot data are presented as mean \pm standard error mean (SEM). These data were analyzed using Student's $t$-test for pairwise or ANOVA for multiple comparisons followed by Scheffés post-hoc test (Statistica version 12; Dell, Tulsa, OK, USA). For all statistical analyses, values of $p<0.05$ were considered significant.

\section{Conclusions}

The aim of the study was to evaluate the expression and potential role of the ECM in RB chemotherapy resistance. Collectively, our data present information regarding ECM and interacting molecules in a chemotherapy resistance model of RB. We assume that the differential ECM expression in the Etoposide resistant compared to the Etoposide sensitive RB cell lines reflects a role of various ECM components in RB cell adhesion, proliferation as well as in chemotherapy resistance. Still, a lot work has to be done, before understanding the whole picture of ECM function and interplay with its enzymes in RB chemotherapy resistance.

Author Contributions: Conceptualization, J.R., A.F., and V.K.; Formal Analysis, J.R. and N.W.; Funding Acquisition, M.M.K., A.F., and V.K.; Methodology, J.R., N.W., M.M.K., M.J., and A.F.; Writing-Original Draft, J.R. and V.K.; Writing-Review \& Editing, S.C.J., H.B.D., and A.F. All authors have read and agreed to the published version of the manuscript.

Funding: We are grateful for grant support (Mercur PR-2011-0010; German Research Foundation, Fa 159/22-1 to A.F., Childhood ocular cancer foundation KAKS20191218f-UKM to V.K., Dr. Werner Jackstädt Stiftung S 143 10.063 to V.K.). M.M.K. was supported by the Karl and Charlotte Spohn Stiftung. We acknowledge support from the DFG Open Access Publication Funds of the Ruhr-Universität Bochum.

Acknowledgments: We thank Stephanie Chun and Sandra Lata for their excellent technical assistance. We thank Petra Temming, Melanie Schwermer, Alexander Schramm, and Harald Stephan (University of Duisburg-Essen, Essen, Germany) for providing the RB cell lines.

Conflicts of Interest: The authors declare no conflict of interest.

\section{Appendix A}

A

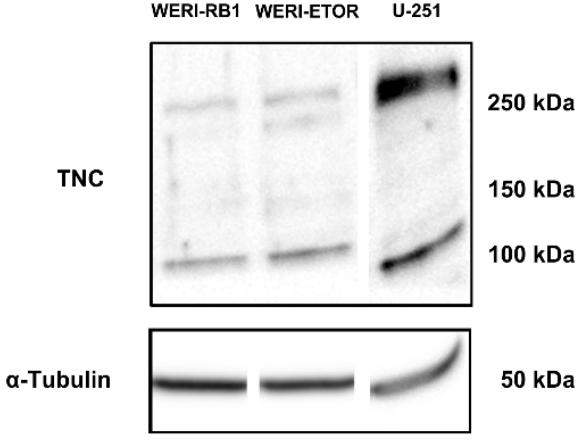

B

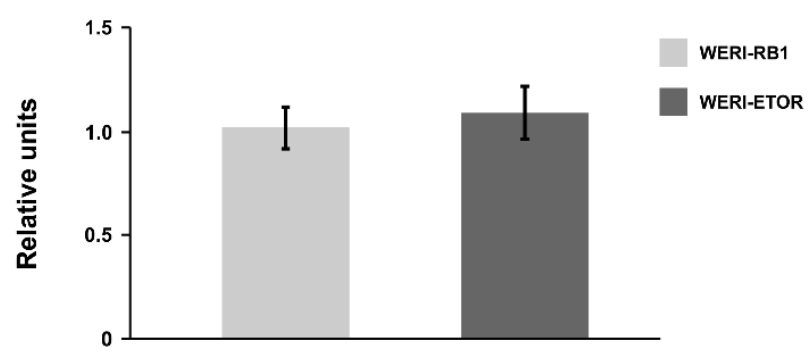

Figure A1. Western blot analyses of TNC in the WERI-RB1 and WERI-ETOR cell line. (A) Representative Western blot analysis using protein lysates of WERI-RB1 and WERI-ETOR cells. Lysate of the glioblastoma cell line U-251 was used as positive control. Distinct bands at $>250,>150$, and $>100 \mathrm{kDa}$ were detectable for TNC. $\alpha$-Tubulin was detectable at $\sim 50 \mathrm{kDa}$. (B) A comparable TNC protein level was noted in both WERI cell lines. Data are shown as mean \pm SEM. $n=4 /$ group. 
A

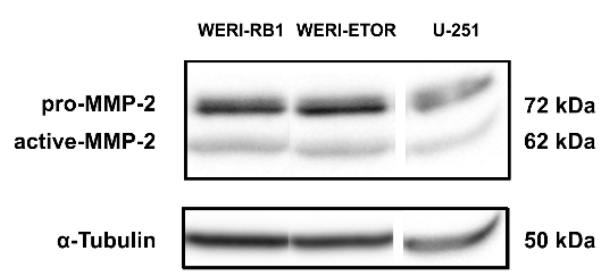

B

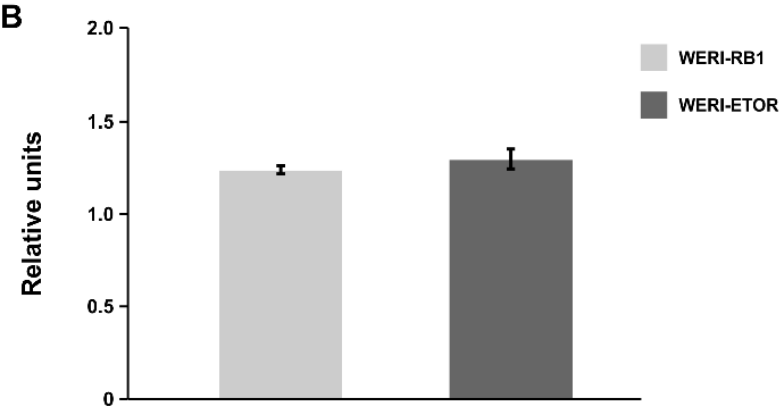

Figure A2. Western blot analyses of the MMP-2 protein in the WERI-RB1 and WERI-ETOR cell line. (A) Representative Western blot analysis using protein lysates of WERI-RB1 and WERI-ETOR cells. Lysate of the glioblastoma cell line U-251 was used as positive control. Pro- and active-MMP-2 protein was detectable at 72 and $62 \mathrm{kDa}$, respectively. $\alpha$-Tubulin was detectable at $\sim 50 \mathrm{kDa}$. (B) A comparable MMP-2 protein concentration was measured in both WERI cell lines. Data are shown as mean \pm SEM. $n=4$ /group.

A

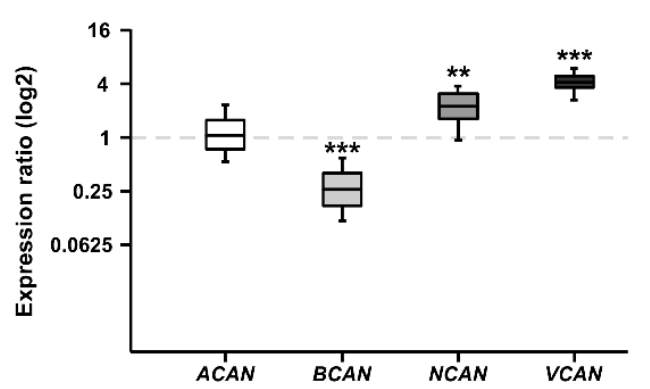

C

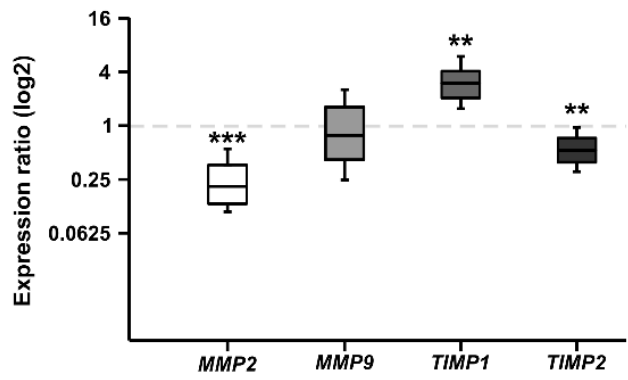

B

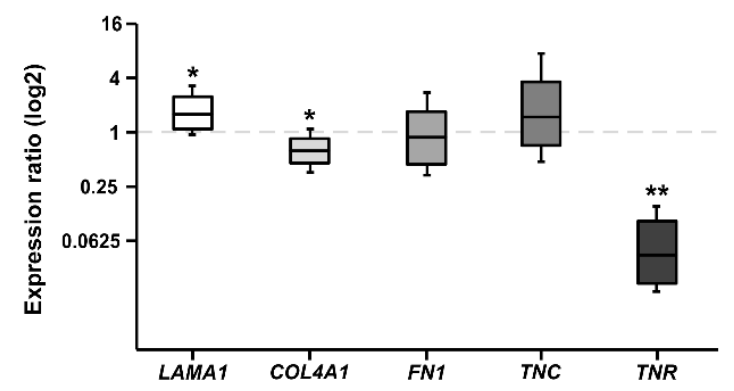

D

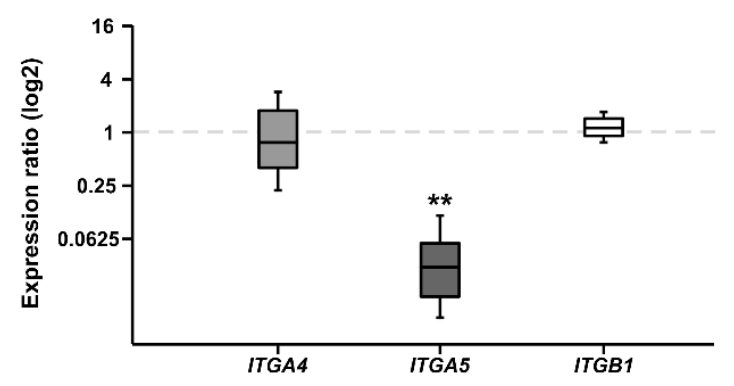

Figure A3. RT-qPCR analyses of relative CSPG, ECM glycoprotein, MMP, TIMP, and Integrin mRNA expression in Etoposide sensitive and resistant $Y 79$ cell lines. (A) A similar ACAN expression was observed in both Y79 cell lines. Significantly reduced $B C A N$ levels were found in resistant compared to sensitive Y79 cells. In contrast, NCAN and VCAN expression levels were significantly higher in the resistant Y79 cell line. (B) The expression of LAMA1 was significantly upregulated in the resistant $Y 79$ cell line. While COL4A1 and TNR were significantly downregulated in resistant Y79 cells. A comparable FN1 and TNC mRNA level was observed in both Y79 cell lines. (C) Significantly reduced expression levels were found for MMP2 and TIMP2. While MMP9 mRNA expression was comparable in both cell lines. TIMP1 was significantly upregulated in the resistant cell line. (D) The resistant Y79 cells showed a significantly reduced ITGA5 expression. ITGA4 and ITGB1 expression was similar in both groups. Values are median \pm quartile + maximum/minimum. The dotted line in the graphs represents the relative expression level of the Etoposide sensitive Y79 cell line. ${ }^{*} p<0.05 ;{ }^{* *} p<0.01$; $* * * \quad p<0.001 ; n=6 /$ group. 


\section{References}

1. Dimaras, H.; Corson, T.W.; Cobrinik, D.; White, A.; Zhao, J.; Munier, F.L.; Abramson, D.H.; Shields, C.L.; Chantada, G.L.; Njuguna, F.; et al. Retinoblastoma. Nat. Rev. Dis. Primers 2015, 1, 15021. [CrossRef] [PubMed]

2. Fabian, I.D.; Onadim, Z.; Karaa, E.; Duncan, C.; Chowdhury, T.; Scheimberg, I.; Ohnuma, S.I.; Reddy, M.A.; Sagoo, M.S. The management of retinoblastoma. Oncogene 2018, 37, 1551-1560. [CrossRef] [PubMed]

3. Dimaras, H.; Kimani, K.; Dimba, E.A.; Gronsdahl, P.; White, A.; Chan, H.S.; Gallie, B.L. Retinoblastoma. Lancet 2012, 379, 1436-1446. [CrossRef]

4. Kivela, T. The epidemiological challenge of the most frequent eye cancer: Retinoblastoma, an issue of birth and death. Br. J. Ophthalmol. 2009, 93, 1129-1131. [CrossRef] [PubMed]

5. Jain, M.; Rojanaporn, D.; Chawla, B.; Sundar, G.; Gopal, L.; Khetan, V. Retinoblastoma in Asia. Eye (Lond.) 2019, 33, 87-96. [CrossRef] [PubMed]

6. Houston, S.K.; Murray, T.G.; Wolfe, S.Q.; Fernandes, C.E. Current update on retinoblastoma. Int. Ophthalmol. Clin. 2011, 51, 77-91. [CrossRef] [PubMed]

7. Ward, E.; DeSantis, C.; Robbins, A.; Kohler, B.; Jemal, A. Childhood and adolescent cancer statistics, 2014. CA Cancer J. Clin. 2014, 64, 83-103. [CrossRef] [PubMed]

8. Sanders, B.M.; Draper, G.J.; Kingston, J.E. Retinoblastoma in Great Britain 1969-80: Incidence, treatment, and survival. Br. J. Ophthalmol. 1988, 72, 576-583. [CrossRef]

9. Abramson, D.H.; Schefler, A.C. Update on retinoblastoma. Retina 2004, 24, 828-848. [CrossRef]

10. Schuler, A.O.; Bornfeld, N. Current therapy aspects of intraocular tumors. Ophthalmologe 2000, 97, $207-222$.

11. Shields, C.L.; De Potter, P.; Himelstein, B.P.; Shields, J.A.; Meadows, A.T.; Maris, J.M. Chemoreduction in the initial management of intraocular retinoblastoma. Arch. Ophthalmol. 1996, 114, 1330-1338. [CrossRef] [PubMed]

12. Friedman, D.L.; Himelstein, B.; Shields, C.L.; Shields, J.A.; Needle, M.; Miller, D.; Bunin, G.R.; Meadows, A.T. Chemoreduction and local ophthalmic therapy for intraocular retinoblastoma. J. Clin. Oncol. 2000, 18, 12-17. [CrossRef] [PubMed]

13. Toma, N.M.; Hungerford, J.L.; Plowman, P.N.; Kingston, J.E.; Doughty, D. External beam radiotherapy for retinoblastoma: II. Lens sparing technique. Br. J. Ophthalmol. 1995, 79, 112-117. [CrossRef] [PubMed]

14. Hungerford, J.L.; Toma, N.M.; Plowman, P.N.; Doughty, D.; Kingston, J.E. Whole-eye versus lens-sparing megavoltage therapy for retinoblastoma. Front. Radiat. Oncol. 1997, 30, 81-87.

15. Abramson, D.H.; Marr, B.P.; Dunkel, I.J.; Brodie, S.; Zabor, E.C.; Driscoll, S.J.; Gobin, Y.P. Intra-arterial chemotherapy for retinoblastoma in eyes with vitreous and/or subretinal seeding: 2-year results. Br. J. Ophthalmol. 2012, 96, 499-502. [CrossRef]

16. Shields, C.L.; Manjandavida, F.P.; Lally, S.E.; Pieretti, G.; Arepalli, S.A.; Caywood, E.H.; Jabbour, P.; Shields, J.A. Intra-arterial chemotherapy for retinoblastoma in 70 eyes: Outcomes based on the international classification of retinoblastoma. Ophthalmology 2014, 121, 1453-1460. [CrossRef]

17. Munier, F.L.; Beck-Popovic, M.; Balmer, A.; Gaillard, M.C.; Bovey, E.; Binaghi, S. Occurrence of sectoral choroidal occlusive vasculopathy and retinal arteriolar embolization after superselective ophthalmic artery chemotherapy for advanced intraocular retinoblastoma. Retina 2011, 31, 566-573. [CrossRef]

18. Jia, M.; Wei, Z.; Liu, P.; Zhao, X. Silencing of ABCG2 by MicroRNA-3163 Inhibits Multidrug Resistance in Retinoblastoma Cancer Stem Cells. J. Korean Med. Sci. 2016, 31, 836-842. [CrossRef]

19. Hoye, A.M.; Erler, J.T. Structural ECM components in the premetastatic and metastatic niche. Am. J. Physiol. Cell Physiol. 2016, 310, C955-C967. [CrossRef]

20. Mongiat, M.; Andreuzzi, E.; Tarticchio, G.; Paulitti, A. Extracellular Matrix, a Hard Player in Angiogenesis. Int. J. Mol. Sci. 2016, 17, 1822. [CrossRef]

21. Van Obberghen-Schilling, E.; Tucker, R.P.; Saupe, F.; Gasser, I.; Cseh, B.; Orend, G. Fibronectin and tenascin-C: Accomplices in vascular morphogenesis during development and tumor growth. Int. J. Dev. Biol. 2011, 55, 511-525. [CrossRef] [PubMed]

22. Venning, F.A.; Wullkopf, L.; Erler, J.T. Targeting ECM Disrupts Cancer Progression. Front. Oncol. 2015, 5, 224. [CrossRef] [PubMed]

23. Piperigkou, Z.; Mohr, B.; Karamanos, N.; Gotte, M. Shed proteoglycans in tumor stroma. Cell Tissue Res. 2016, 365, 643-655. [CrossRef] [PubMed] 
24. Martin, M.; Wei, H.; Lu, T. Targeting microenvironment in cancer therapeutics. Oncotarget 2016, 7, 52575-52583. [CrossRef] [PubMed]

25. Mittal, R.; Patel, A.P.; Debs, L.H.; Nguyen, D.; Patel, K.; Grati, M.; Mittal, J.; Yan, D.; Chapagain, P.; Liu, X.Z. Intricate Functions of Matrix Metalloproteinases in Physiological and Pathological Conditions. J. Cell Physiol. 2016, 231, 2599-2621. [CrossRef]

26. Kapoor, C.; Vaidya, S.; Hitesh, V.W.; Kaur, G.; Pathak, A. Seesaw of matrix metalloproteinases (MMPs). J. Cancer Res. 2016, 12, 28-35.

27. Lu, P.; Weaver, V.M.; Werb, Z. The extracellular matrix: A dynamic niche in cancer progression. J. Cell Biol. 2012, 196, 395-406. [CrossRef]

28. Hodkinson, P.S.; Mackinnon, A.C.; Sethi, T. Extracellular matrix regulation of drug resistance in small-cell lung cancer. Int. J. Radiat. Biol. 2007, 83, 733-741. [CrossRef]

29. Reinhard, J.; Brosicke, N.; Theocharidis, U.; Faissner, A. The extracellular matrix niche microenvironment of neural and cancer stem cells in the brain. Int. J. Biochem. Cell Biol. 2016, 81, 174-183. [CrossRef]

30. Seigel, G.M.; Campbell, L.M.; Narayan, M.; Gonzalez-Fernandez, F. Cancer stem cell characteristics in retinoblastoma. Mol. Vis. 2005, 11, 729-737.

31. Seigel, G.M.; Hackam, A.S.; Ganguly, A.; Mandell, L.M.; Gonzalez-Fernandez, F. Human embryonic and neuronal stem cell markers in retinoblastoma. Mol. Vis. 2007, 13, 823-832.

32. Balla, M.M.; Vemuganti, G.K.; Kannabiran, C.; Honavar, S.G.; Murthy, R. Phenotypic characterization of retinoblastoma for the presence of putative cancer stem-like cell markers by flow cytometry. Invest. Ophthalmol. Vis. Sci. 2009, 50, 1506-15014. [CrossRef] [PubMed]

33. Zhong, X.; Li, Y.; Peng, F.; Huang, B.; Lin, J.; Zhang, W.; Zheng, J.; Jiang, R.; Song, G.; Ge, J. Identification of tumorigenic retinal stem-like cells in human solid retinoblastomas. Int. J. Cancer 2007, 121, 2125-2131. [CrossRef] [PubMed]

34. Shukla, S.; Srivastava, A.; Kumar, S.; Singh, U.; Goswami, S.; Chawla, B.; Bajaj, M.S.; Kashyap, S.; Kaur, J. Expression of multidrug resistance proteins in retinoblastoma. Int. J. Ophthalmol. 2017, 10, 1655-1661. [PubMed]

35. McFall, R.C.; Sery, T.W.; Makadon, M. Characterization of a new continuous cell line derived from a human retinoblastoma. Cancer Res. 1977, 37, 1003-1010. [PubMed]

36. Stephan, H.; Boeloeni, R.; Eggert, A.; Bornfeld, N.; Schueler, A. Photodynamic therapy in retinoblastoma: Effects of verteporfin on retinoblastoma cell lines. Invest. Ophthalmol. Vis. Sci. 2008, 49, 3158-3163. [CrossRef]

37. Mergler, S.; Cheng, Y.; Skosyrski, S.; Garreis, F.; Pietrzak, P.; Kociok, N.; Dwarakanath, A.; Reinach, P.S.; Kakkassery, V. Altered calcium regulation by thermosensitive transient receptor potential channels in etoposide-resistant WERI-Rb1 retinoblastoma cells. Exp. Eye Res. 2012, 94, 157-173. [CrossRef]

38. Kakkassery, V.; Skosyrski, S.; Luth, A.; Kleuser, B.; van der Giet, M.; Tate, R.; Reinhard, J.; Faissner, A.; Joachim, S.C.; Kociok, N. Etoposide Upregulates Survival Favoring Sphingosine-1-Phosphate in Etoposide-Resistant Retinoblastoma Cells. Pathol. Oncol. Res. 2019, 25, 391-399. [CrossRef]

39. Reid, T.W.; Albert, D.M.; Rabson, A.S.; Russell, P.; Craft, J.; Chu, E.W.; Tralka, T.S.; Wilcox, J.L. Characteristics of an established cell line of retinoblastoma. J. Natl. Cancer Inst. 1974, 53, 347-360. [CrossRef]

40. Bourboulia, D.; Stetler-Stevenson, W.G. Matrix metalloproteinases (MMPs) and tissue inhibitors of metalloproteinases (TIMPs): Positive and negative regulators in tumor cell adhesion. Semin. Cancer Biol. 2010, 20, 161-168. [CrossRef]

41. Xiong, J.; Balcioglu, H.E.; Danen, E.H. Integrin signaling in control of tumor growth and progression. Int. J. Biochem. Cell Biol. 2013, 45, 1012-1015. [CrossRef]

42. Missan, D.S.; DiPersio, M. Integrin control of tumor invasion. Crit. Rev. Eukaryot. Gene Expr. 2012, 22, 309-324. [CrossRef]

43. Barnea, G.; Grumet, M.; Milev, P.; Silvennoinen, O.; Levy, J.B.; Sap, J.; Schlessinger, J. Receptor tyrosine phosphatase beta is expressed in the form of proteoglycan and binds to the extracellular matrix protein tenascin. J. Biol. Chem. 1994, 269, 14349-14352.

44. Grumet, M.; Milev, P.; Sakurai, T.; Karthikeyan, L.; Bourdon, M.; Margolis, R.K.; Margolis, R.U. Interactions with tenascin and differential effects on cell adhesion of neurocan and phosphacan, two major chondroitin sulfate proteoglycans of nervous tissue. J. Biol. Chem. 1994, 269, 12142-12146.

45. Norman, S.A.; Golfinos, J.G.; Scheck, A.C. Expression of a receptor protein tyrosine phosphatase in human glial tumors. J. Neurooncol. 1998, 36, 209-217. [CrossRef] [PubMed] 
46. Henke, E.; Nandigama, R.; Ergun, S. Extracellular Matrix in the Tumor Microenvironment and Its Impact on Cancer Therapy. Front. Mol. Biosci. 2019, 6, 160. [CrossRef] [PubMed]

47. Karamanos, N.K. Special issue: Translating extracellular matrix: From cancer progression to therapeutics. Semin. Cancer Biol. 2020, 62, iii-v. [CrossRef] [PubMed]

48. Rauch, U. Extracellular matrix components associated with remodeling processes in brain. Cell Mol. Life Sci. 2004, 61, 2031-2045. [CrossRef] [PubMed]

49. Varga, I.; Hutoczki, G.; Szemcsak, C.D.; Zahuczky, G.; Toth, J.; Adamecz, Z.; Kenyeres, A.; Bognar, L.; Hanzely, Z.; Klekner, A. Brevican, neurocan, tenascin-C and versican are mainly responsible for the invasiveness of low-grade astrocytoma. Pathol. Oncol. Res. 2012, 18, 413-420. [CrossRef]

50. Lu, P.; Takai, K.; Weaver, V.M.; Werb, Z. Extracellular matrix degradation and remodeling in development and disease. Cold Spring Harb. Perspect. Biol. 2011, 3, a005058. [CrossRef]

51. Dwyer, C.A.; Bi, W.L.; Viapiano, M.S.; Matthews, R.T. Brevican knockdown reduces late-stage glioma tumor aggressiveness. J. Neurooncol. 2014, 120, 63-72. [CrossRef] [PubMed]

52. Asimakopoulou, A.P.; Theocharis, A.D.; Tzanakakis, G.N.; Karamanos, N.K. The biological role of chondroitin sulfate in cancer and chondroitin-based anticancer agents. Vivo 2008, 22, 385-389.

53. Kim, S.; Takahashi, H.; Lin, W.W.; Descargues, P.; Grivennikov, S.; Kim, Y.; Luo, J.L.; Karin, M. Carcinoma-produced factors activate myeloid cells through TLR2 to stimulate metastasis. Nature 2009, 457, 102-106. [CrossRef] [PubMed]

54. Isogai, Z.; Shinomura, T.; Yamakawa, N.; Takeuchi, J.; Tsuji, T.; Heinegard, D.; Kimata, K. $2 \mathrm{~B} 1$ antigen characteristically expressed on extracellular matrices of human malignant tumors is a large chondroitin sulfate proteoglycan, PG-M/versican. Cancer Res. 1996, 56, 3902-3908. [PubMed]

55. Pirinen, R.; Leinonen, T.; Bohm, J.; Johansson, R.; Ropponen, K.; Kumpulainen, E.; Kosma, V.M. Versican in nonsmall cell lung cancer: Relation to hyaluronan, clinicopathologic factors, and prognosis. Hum. Pathol. 2005, 36, 44-50. [CrossRef]

56. Quirico-Santos, T.; Fonseca, C.O.; Lagrota-Candido, J. Brain sweet brain: Importance of sugars for the cerebral microenvironment and tumor development. Arq. Neuropsiquiatr. 2010, 68, 799-803. [CrossRef]

57. Abaskharoun, M.; Bellemare, M.; Lau, E.; Margolis, R.U. Expression of hyaluronan and the hyaluronan-binding proteoglycans neurocan, aggrecan, and versican by neural stem cells and neural cells derived from embryonic stem cells. Brain Res. 2010, 1327, 6-15. [CrossRef]

58. Klausmeyer, A.; Garwood, J.; Faissner, A. Differential expression of phosphacan/RPTPbeta isoforms in the developing mouse visual system. J. Comp. Neurol. 2007, 504, 659-679. [CrossRef]

59. Popp, S.; Andersen, J.S.; Maurel, P.; Margolis, R.U. Localization of aggrecan and versican in the developing rat central nervous system. Dev. Dyn. 2003, 227, 143-149. [CrossRef]

60. Felemban, M.; Dorgau, B.; Hunt, N.C.; Hallam, D.; Zerti, D.; Bauer, R.; Ding, Y.; Collin, J.; Steel, D.; Krasnogor, N.; et al. Extracellular matrix component expression in human pluripotent stem cell-derived retinal organoids recapitulates retinogenesis in vivo and reveals an important role for IMPG1 and CD44 in the development of photoreceptors and interphotoreceptor matrix. Acta Biomater. 2018, 74, 207-221. [CrossRef]

61. Senthebane, D.A.; Jonker, T.; Rowe, A.; Thomford, N.E.; Munro, D.; Dandara, C.; Wonkam, A.; Govender, D.; Calder, B.; Soares, N.C.; et al. The Role of Tumor Microenvironment in Chemoresistance: 3D Extracellular Matrices as Accomplices. Int. J. Mol. Sci. 2018, 19, 2861. [CrossRef] [PubMed]

62. Ohlund, D.; Franklin, O.; Lundberg, E.; Lundin, C.; Sund, M. Type IV collagen stimulates pancreatic cancer cell proliferation, migration, and inhibits apoptosis through an autocrine loop. BMC Cancer 2013, 13, 154. [CrossRef] [PubMed]

63. Miyamoto, H.; Murakami, T.; Tsuchida, K.; Sugino, H.; Miyake, H.; Tashiro, S. Tumor-stroma interaction of human pancreatic cancer: Acquired resistance to anticancer drugs and proliferation regulation is dependent on extracellular matrix proteins. Pancreas 2004, 28, 38-44. [CrossRef]

64. Burnier, J.V.; Wang, N.; Michel, R.P.; Hassanain, M.; Li, S.; Lu, Y.; Metrakos, P.; Antecka, E.; Burnier, M.N.; Ponton, A.; et al. Type IV collagen-initiated signals provide survival and growth cues required for liver metastasis. Oncogene 2011, 30, 3766-3783. [CrossRef]

65. Campochiaro, P.A.; Jerdon, J.A.; Glaser, B.M. The extracellular matrix of human retinal pigment epithelial cells in vivo and its synthesis in vitro. Invest. Ophthalmol. Vis. Sci. 1986, 27, 1615-1621. [PubMed] 
66. Pina, Y.; Boutrid, H.; Schefler, A.; Dubovy, S.; Feuer, W.; Jockovich, M.E.; Murray, T.G. Blood vessel maturation in retinoblastoma tumors: Spatial distribution of neovessels and mature vessels and its impact on ocular treatment. Invest. Ophthalmol. Vis. Sci. 2009, 50, 1020-1024. [CrossRef]

67. Jockovich, M.E.; Pina, Y.; Alegret, A.; Cebulla, C.; Feuer, W.; Murray, T.G. Heterogeneous tumor vasculature in retinoblastoma: Implications for vessel targeting therapy. Retina 2008, 28 (Suppl. 3), S81-S86. [CrossRef]

68. Fang, M.; Yuan, J.; Peng, C.; Li, Y. Collagen as a double-edged sword in tumor progression. Tumour. Biol. 2014, 35, 2871-2882. [CrossRef]

69. Skubitz, A.P.; Grossman, M.D.; McCarthy, J.B.; Wayner, E.A.; Cameron, J.D. The decreased adhesion of Y79 retinoblastoma cells to extracellular matrix proteins is due to a deficit of integrin receptors. Invest. Ophthalmol. Vis. Sci. 1994, 35, 2820-2833.

70. Nowak, M.; Freudenberg, U.; Tsurkan, M.V.; Werner, C.; Levental, K.R. Modular GAG-matrices to promote mammary epithelial morphogenesis in vitro. Biomaterials 2017, 112, 20-30. [CrossRef]

71. Taylor, M.A.; Amin, J.D.; Kirschmann, D.A.; Schiemann, W.P. Lysyl oxidase contributes to mechanotransduction-mediated regulation of transforming growth factor-beta signaling in breast cancer cells. Neoplasia 2011, 13, 406-418. [CrossRef]

72. Rossow, L.; Veitl, S.; Vorlova, S.; Wax, J.K.; Kuhn, A.E.; Maltzahn, V.; Upcin, B.; Karl, F.; Hoffmann, H.; Gatzner, S.; et al. LOX-catalyzed collagen stabilization is a proximal cause for intrinsic resistance to chemotherapy. Oncogene 2018, 37, 4921-4940. [CrossRef] [PubMed]

73. Baker, A.M.; Bird, D.; Welti, J.C.; Gourlaouen, M.; Lang, G.; Murray, G.I.; Reynolds, A.R.; Cox, T.R.; Erler, J.T. Lysyl oxidase plays a critical role in endothelial cell stimulation to drive tumor angiogenesis. Cancer Res. 2013, 73, 583-594. [CrossRef]

74. Baker, A.M.; Bird, D.; Lang, G.; Cox, T.R.; Erler, J.T. Lysyl oxidase enzymatic function increases stiffness to drive colorectal cancer progression through FAK. Oncogene 2013, 32, 1863-1868. [CrossRef] [PubMed]

75. Gorres, K.L.; Raines, R.T. Prolyl 4-hydroxylase. Crit. Rev. Biochem. Mol. Biol. 2010, 45, 106-124. [CrossRef] [PubMed]

76. Xiong, G.; Deng, L.; Zhu, J.; Rychahou, P.G.; Xu, R. Prolyl-4-hydroxylase alpha subunit 2 promotes breast cancer progression and metastasis by regulating collagen deposition. BMC Cancer 2014, 14, 1. [CrossRef] [PubMed]

77. Xiong, G.; Stewart, R.L.; Chen, J.; Gao, T.; Scott, T.L.; Samayoa, L.M.; O'Connor, K.; Lane, A.N.; Xu, R. Collagen prolyl 4-hydroxylase 1 is essential for HIF-1alpha stabilization and TNBC chemoresistance. Nat. Commun. 2018, 9, 4456. [CrossRef]

78. Akiyama, S.K.; Olden, K.; Yamada, K.M. Fibronectin and integrins in invasion and metastasis. Cancer Metastasis. Rev. 1995, 14, 173-189. [CrossRef]

79. Bae, Y.K.; Kim, A.; Kim, M.K.; Choi, J.E.; Kang, S.H.; Lee, S.J. Fibronectin expression in carcinoma cells correlates with tumor aggressiveness and poor clinical outcome in patients with invasive breast cancer. Hum. Pathol. 2013, 44, 2028-2037. [CrossRef]

80. Li, Y.; Miao, L.; Yu, M.; Shi, M.; Wang, Y.; Yang, J.; Xiao, Y.; Cai, H. alpha1-antitrypsin promotes lung adenocarcinoma metastasis through upregulating fibronectin expression. Int. J. Oncol. 2017, 50, 1955-1964. [CrossRef]

81. Zhang, M.J.; Yan, Q.; Zhang, G.L.; Wie, Y.H.; Yuan, W.B.; Xu, W.; Huang, L.F. Expression and Prognostic Role of FHIT, Fibronectin, and PTEN in Hepatocellular Carcinoma. Clin. Lab. 2016, 62, 1255-1264. [CrossRef] [PubMed]

82. Wang, J.P.; Hielscher, A. Fibronectin: How Its Aberrant Expression in Tumors May Improve Therapeutic Targeting. J. Cancer. 2017, 8, 674-682. [CrossRef] [PubMed]

83. Das, S.; Banerji, A.; Frei, E.; Chatterjee, A. Rapid expression and activation of MMP-2 and MMP-9 upon exposure of human breast cancer cells (MCF-7) to fibronectin in serum free medium. Life Sci. 2008, 82, 467-476. [CrossRef]

84. Reinhard, J.; Roll, L.; Faissner, A. Tenascins in Retinal and Optic Nerve Neurodegeneration. Front. Integr. Neurosci. 2017, 11, 30. [CrossRef] [PubMed]

85. Reinhard, J.; Joachim, S.C.; Faissner, A. Extracellular matrix remodeling during retinal development. Exp. Eye Res. 2015, 133, 132-140. [CrossRef] [PubMed]

86. Brosicke, N.; van Landeghem, F.K.; Scheffler, B.; Faissner, A. Tenascin-C is expressed by human glioma in vivo and shows a strong association with tumor blood vessels. Cell Tissue Res. 2013, 354, 409-430. [CrossRef] 
87. Chiquet-Ehrismann, R.; Tucker, R.P. Tenascins and the importance of adhesion modulation. Cold Spring Harb. Perspect. Biol. 2011, 3, a004960. [CrossRef]

88. Kim, C.H.; Bak, K.H.; Kim, Y.S.; Kim, J.M.; Ko, Y.; Oh, S.J.; Kim, K.M.; Hong, E.K. Expression of tenascin-C in astrocytic tumors: Its relevance to proliferation and angiogenesis. Surg. Neurol. 2000, 54, 235-240. [CrossRef]

89. Gong, X.G.; Lv, Y.F.; Li, X.Q.; Xu, F.G.; Ma, Q.Y. Gemcitabine resistance induced by interaction between alternatively spliced segment of tenascin-C and annexin A2 in pancreatic cancer cells. Biol. Pharm. Bull. 2010, 33, 1261-1267. [CrossRef]

90. Tang, Y.A.; Chen, C.H.; Sun, H.S.; Cheng, C.P.; Tseng, V.S.; Hsu, H.S.; Su, W.C.; Lai, W.W.; Wang, Y.C. Global Oct4 target gene analysis reveals novel downstream PTEN and TNC genes required for drug-resistance and metastasis in lung cancer. Nucleic Acids Res. 2015, 43, 1593-1608. [CrossRef]

91. Shi, M.; He, X.; Wei, W.; Wang, J.; Zhang, T.; Shen, X. Tenascin-C induces resistance to apoptosis in pancreatic cancer cell through activation of ERK/NF-kappaB pathway. Apoptosis 2015, 20, 843-857. [CrossRef] [PubMed]

92. Naik, A.; Al-Yahyaee, A.; Abdullah, N.; Sam, J.E.; Al-Zeheimi, N.; Yaish, M.W.; Adham, S.A. Neuropilin-1 promotes the oncogenic Tenascin-C/integrin beta3 pathway and modulates chemoresistance in breast cancer cells. BMC Cancer 2018, 18, 533. [CrossRef] [PubMed]

93. Sugawara, I.; Hirakoshi, J.; Kusakabe, M.; Masunaga, A.; Itoyama, S.; Sakakura, T. Relationships among tenascin expression, DNA ploidy patterns, and multidrug resistance gene product (P-glycoprotein) in human colon carcinoma. Jpn. J. Cancer Res. 1993, 84, 703-707. [CrossRef]

94. Brosicke, N.; Faissner, A. Role of tenascins in the ECM of gliomas. Cell Adh. Migr. 2015, 9, 131-140. [CrossRef]

95. Pesheva, P.; Probstmeier, R.; Skubitz, A.P.; McCarthy, J.B.; Furcht, L.T.; Schachner, M. Tenascin-R (J1 160/180 inhibits fibronectin-mediated cell adhesion-functional relatedness to tenascin-C. J. Cell Sci. 1994, 107, 2323-2333. [PubMed]

96. Long, H.; Zhou, B.; Jiang, F.G. Expression of MMP-2 and MMP-9 in retinoblastoma and their significance. Int. J. Ophthalmol. 2011, 4, 489-491. [PubMed]

97. Adithi, M.; Nalini, V.; Kandalam, M.; Krishnakumar, S. Expression of matrix metalloproteinases and their inhibitors in retinoblastoma. J. Pediatr. Hematol. Oncol. 2007, 29, 399-405. [CrossRef]

98. Webb, A.H.; Gao, B.T.; Goldsmith, Z.K.; Irvine, A.S.; Saleh, N.; Lee, R.P.; Lendermon, J.B.; Bheemreddy, R.; Zhang, Q.; Brennan, R.C.; et al. Inhibition of MMP-2 and MMP-9 decreases cellular migration, and angiogenesis in in vitro models of retinoblastoma. BMC Cancer 2017, 17, 434. [CrossRef]

99. Jeleniewicz, W.; Cybulski, M.; Nowakowski, A.; Stenzel-Bembenek, A.; Guz, M.; Marzec-Kotarska, B.; Kotarski, J.; Stepulak, A. MMP-2 mRNA Expression in Ovarian Cancer Tissues Predicts Patients' Response to Platinum-Taxane Chemotherapy. Anticancer. Res. 2019, 39, 1821-1827. [CrossRef]

100. Nalluri, S.; Ghoshal-Gupta, S.; Kutiyanawalla, A.; Gayatri, S.; Lee, B.R.; Jiwani, S.; Rojiani, A.M.; Rojiani, M.V. TIMP-1 Inhibits Apoptosis in Lung Adenocarcinoma Cells via Interaction with Bcl-2. PLoS ONE 2015, 10, e0137673. [CrossRef]

101. Jiang, H.W.; Zhu, H.Y.; Wang, J.Z.; Fu, B.; Lu, Y.; Hong, Q.; Xie, Y.S.; Chen, X.M. Tissue inhibitor of metalloproteinase-1 counteracts glucolipotoxicity in the pancreatic beta-cell line INS-1. Chin. Med. J. Engl. 2011, 124, 258-261. [PubMed]

102. Li, Y.; Yang, X.; Du, X.; Lei, Y.; He, Q.; Hong, X.; Tang, X.; Wen, X.; Zhang, P.; Sun, Y.; et al. RAB37 Hypermethylation Regulates Metastasis and Resistance to Docetaxel-Based Induction Chemotherapy in Nasopharyngeal Carcinoma. Clin. Cancer Res. 2018, 24, 6495-6508. [CrossRef] [PubMed]

103. Miyake, H.; Nishikawa, M.; Tei, H.; Furukawa, J.; Harada, K.; Fujisawa, M. Significance of circulating matrix metalloproteinase- 9 to tissue inhibitor of metalloproteinases-2 ratio as a predictor of disease progression in patients with metastatic renal cell carcinoma receiving sunitinib. Urol. Oncol. 2014, 32, 584-588. [CrossRef] [PubMed]

104. Halon, A.; Nowak-Markwitz, E.; Donizy, P.; Matkowski, R.; Maciejczyk, A.; Gansukh, T.; Gyorffy, B.; Spaczynski, M.; Zabel, M.; Lage, H.; et al. Enhanced immunoreactivity of TIMP-2 in the stromal compartment of tumor as a marker of favorable prognosis in ovarian cancer patients. J. Histochem. Cytochem. 2012, 60, 491-501. [CrossRef] [PubMed]

105. Waleh, N.S.; Murphy, B.J.; Zaveri, N.T. Increase in tissue inhibitor of metalloproteinase-2 (TIMP-2) levels and inhibition of MMP-2 activity in a metastatic breast cancer cell line by an anti-invasive small molecule SR13179. Cancer Lett. 2010, 289, 111-118. [CrossRef] 
106. Wang, Y.; Shenouda, S.; Baranwal, S.; Rathinam, R.; Jain, P.; Bao, L.; Hazari, S.; Dash, S.; Alahari, S.K. Integrin subunits alpha 5 and alpha6 regulate cell cycle by modulating the chk1 and Rb/E2F pathways to affect breast cancer metastasis. Mol. Cancer 2011, 10, 84. [CrossRef]

107. Gong, L.; Zheng, Y.; Liu, S.; Peng, Z. Fibronectin Regulates the Dynamic Formation of Ovarian Cancer Multicellular Aggregates and the Expression of Integrin Receptors. Asian Pac. J. Cancer Prev. 2018, 19, 2493-2498.

108. Muller-Tidow, C.; Ji, P.; Diederichs, S.; Potratz, J.; Baumer, N.; Kohler, G.; Cauvet, T.; Choudary, C.; van der Meer, T.; Chan, W.Y.; et al. The cyclin A1-CDK2 complex regulates DNA double-strand break repair. Mol. Cell Biol. 2004, 24, 8917-8928. [CrossRef]

109. Janouskova, H.; Maglott, A.; Leger, D.Y.; Bossert, C.; Noulet, F.; Guerin, E.; Guenot, D.; Pinel, S.; Chastagner, P.; Plenat, F.; et al. Integrin alpha5beta1 plays a critical role in resistance to temozolomide by interfering with the p53 pathway in high-grade glioma. Cancer Res. 2012, 72, 3463-3470. [CrossRef]

110. Jacquemet, G.; Green, D.M.; Bridgewater, R.E.; von Kriegsheim, A.; Humphries, M.J.; Norman, J.C.; Caswell, P.T. RCP-driven alpha5beta1 recycling suppresses Rac and promotes RhoA activity via the RacGAP1-IQGAP1 complex. J. Cell Biol. 2013, 202, 917-935. [CrossRef]

111. Muller, P.A.; Caswell, P.T.; Doyle, B.; Iwanicki, M.P.; Tan, E.H.; Karim, S.; Lukashchuk, N.; Gillespie, D.A.; Ludwig, R.L.; Gosselin, P.; et al. Mutant p53 drives invasion by promoting integrin recycling. Cell 2009, 139, 1327-1341. [CrossRef] [PubMed]

112. Koutsioumpa, M.; Poimenidi, E.; Pantazaka, E.; Theodoropoulou, C.; Skoura, A.; Megalooikonomou, V.; Kieffer, N.; Courty, J.; Mizumoto, S.; Sugahara, K.; et al. Receptor protein tyrosine phosphatase beta/zeta is a functional binding partner for vascular endothelial growth factor. Mol. Cancer 2015, 14, 19. [CrossRef] [PubMed]

113. Diamantopoulou, Z.; Kitsou, P.; Menashi, S.; Courty, J.; Katsoris, P. Loss of receptor protein tyrosine phosphatase beta/zeta (RPTPbeta/zeta) promotes prostate cancer metastasis. J. Biol. Chem. 2012, 287, 40339-40349. [CrossRef]

114. Rauch, U.; Clement, A.; Retzler, C.; Frohlich, L.; Fassler, R.; Gohring, W.; Faissner, A. Mapping of a defined neurocan binding site to distinct domains of tenascin-C. J. Biol. Chem. 1997, 272, 26905-26912. [CrossRef] [PubMed]

115. Yokosaki, Y.; Matsuura, N.; Higashiyama, S.; Murakami, I.; Obara, M.; Yamakido, M.; Shigeto, N.; Chen, J.; Sheppard, D. Identification of the ligand binding site for the integrin alpha9 beta1 in the third fibronectin type III repeat of tenascin-C. J. Biol. Chem. 1998, 273, 11423-11428. [CrossRef] [PubMed]

116. Siri, A.; Knauper, V.; Veirana, N.; Caocci, F.; Murphy, G.; Zardi, L. Different susceptibility of small and large human tenascin-C isoforms to degradation by matrix metalloproteinases. J. Biol. Chem. 1995, 270, 8650-8654. [CrossRef] [PubMed]

117. Jang, J.H.; Chung, C.P. Tenascin-C promotes cell survival by activation of Akt in human chondrosarcoma cell. Cancer Lett. 2005, 229, 101-105. [CrossRef]

118. Ni, W.D.; Yang, Z.T.; Cui, C.A.; Cui, Y.; Fang, L.Y.; Xuan, Y.H. Tenascin-C is a potential cancer-associated fibroblasts marker and predicts poor prognosis in prostate cancer. Biochem. Biophys. Res. Commun. 2017, 486, 607-612. [CrossRef]

119. Yang, Z.; Ni, W.; Cui, C.; Fang, L.; Xuan, Y. Tenascin C is a prognostic determinant and potential cancer-associated fibroblasts marker for breast ductal carcinoma. Exp. Mol. Pathol. 2017, 102, 262-267. [CrossRef]

120. Morgan, M.; Saba, S.; Gower, W. Fibronectin influences cellular proliferation and apoptosis similarly in LNCaP and PC-3 prostate cancer cell lines. Urol. Oncol. 2000, 5, 155-159. [CrossRef]

121. Raffo, A.J.; Perlman, H.; Chen, M.W.; Day, M.L.; Streitman, J.S.; Buttyan, R. Overexpression of bcl-2 protects prostate cancer cells from apoptosis in vitro and confers resistance to androgen depletion in vivo. Cancer Res. 1995, 55, 4438-4445. [PubMed]

122. De Jong-Hesse, Y.; Kampmeier, J.; Lang, G.K.; Lang, G.E. Effect of extracellular matrix on proliferation and differentiation of porcine lens epithelial cells. Graefes Arch. Clin. Exp. Ophthalmol. 2005, 243, 695-700. [CrossRef]

123. Illario, M.; Cavallo, A.L.; Monaco, S.; Di Vito, E.; Mueller, F.; Marzano, L.A.; Troncone, G.; Fenzi, G.; Rossi, G.; Vitale, M. Fibronectin-induced proliferation in thyroid cells is mediated by alphavbeta3 integrin through Ras/Raf-1/MEK/ERK and calcium/CaMKII signals. J. Clin. Endocrinol.Metab. 2005, 90, 2865-2873. [CrossRef] [PubMed] 
124. Orend, G.; Huang, W.; Olayioye, M.A.; Hynes, N.E.; Chiquet-Ehrismann, R. Tenascin-C blocks cell-cycle progression of anchorage-dependent fibroblasts on fibronectin through inhibition of syndecan-4. Oncogene 2003, 22, 3917-3926. [CrossRef] [PubMed]

125. Molnar, B.; Ladanyi, A.; Tanko, L.; Sreter, L.; Tulassay, Z. Circulating tumor cell clusters in the peripheral blood of colorectal cancer patients. Clin. Cancer Res. 2001, 7, 4080-4085. [PubMed]

126. Yu, M.; Bardia, A.; Wittner, B.S.; Stott, S.L.; Smas, M.E.; Ting, D.T.; Isakoff, S.J.; Ciciliano, J.C.; Wells, M.N.; Shah, A.M.; et al. Circulating breast tumor cells exhibit dynamic changes in epithelial and mesenchymal composition. Science 2013, 339, 580-584. [CrossRef]

127. Radwanska, A.; Grall, D.; Schaub, S.; Divonne, S.B.F.; Ciais, D.; Rekima, S.; Rupp, T.; Sudaka, A.; Orend, G.; Van Obberghen-Schilling, E. Counterbalancing anti-adhesive effects of Tenascin-C through fibronectin expression in endothelial cells. Sci. Rep. 2017, 7, 12762. [CrossRef]

128. Faissner, A.; Kruse, J. J1/tenascin is a repulsive substrate for central nervous system neurons. Neuron 1990, 5, 627-637. [CrossRef]

129. Pfaffl, M.W.; Horgan, G.W.; Dempfle, L. Relative expression software tool (REST) for group-wise comparison and statistical analysis of relative expression results in real-time PCR. Nucleic Acids Res. 2002, 30, e36. [CrossRef] [PubMed]

(C) 2020 by the authors. Licensee MDPI, Basel, Switzerland. This article is an open access article distributed under the terms and conditions of the Creative Commons Attribution (CC BY) license (http://creativecommons.org/licenses/by/4.0/). 